1

2

3

\title{
Multiple episodes of fast exhumation since Cretaceous in southeast Tibet, revealed by low-temperature thermochronology
}

\author{
Jing Liu-Zeng* ${ }^{1}$, Jinyu Zhang ${ }^{1}$, Devin McPhillips ${ }^{2}$, Peter Reiners ${ }^{3}$, Wei Wang ${ }^{1}$, Raphael \\ Pik $^{4}$, Lingsen Zeng ${ }^{5}$, Greg Hoke ${ }^{2}$, Kejia Xie ${ }^{1}$, Ping Xiao ${ }^{1}$, Dewen Zheng ${ }^{1}$, and Yukui Ge ${ }^{1}$ \\ 1. State Key Laboratory of Earthquake Dynamics, Institute of Geology, China Earthquake Administration, \\ China \\ 2. Syracuse University, Earth Sciences, Syracuse, NY, United States \\ 3. Department of Geosciences, University of Arizona, U.S.A \\ 4. CRPG, Nancy, France \\ 5. Institute of Geology, Chinese Geological Academy, China \\ * Corresponding author: \\ J. Liu-Zeng, \\ Institute of Geology, China Earthquake Administration \\ \#A1 Huayanli, Chaoyang District \\ Beijing 100029 \\ China \\ liu-zeng@ies.ac.cn \\ +861062009018 phone
}


Abstract

The southeast margin of the Tibetan plateau is characterized by deeply incised river valleys separated by a perched low relief landscape that gently descends from the high Tibetan plateau towards the southeast. When and how this unique landscape formed is debated. The onset of increased river incision is often interpreted as a proxy for the timing of surface uplift. Here, apatite and zircon (U-Th)/He and apatite fission track thermochronometries are employed to map the spatial and temporal pattern of exhumation in the region. Vertical profiles of granitic rocks were collected near Deqin $\left(\sim 28.5^{\circ} \mathrm{N}\right)$ and Weixi $\left(\sim 27.5^{\circ} \mathrm{N}\right)$. The two transects share a similar exhumation history, with two episodes of relatively fast exhumation $(\sim 100-300 \mathrm{~m} / \mathrm{Myr})$ in the Cenozoic: during the Paleocene to Eocene (60-40 Ma) and Miocene to present (20-0 Ma), separated by an intervening period of slow exhumation. A pulse of moderate to high exhumation $(70-300 \mathrm{~m} / \mathrm{Myr})$ during the midto late-Cretaceous (120-80 Ma) is also present in the data. However, the rate and total amount of exhumation near Deqin is larger than at Weixi and is especially pronounced in the interval between $20 \mathrm{Ma}$ to present. We interpret this difference as possibly related to differences in erosion rates between the Lancang (Deqin) and the Jinsha (Weixi) rivers. The Paleocene to Eocene episode of fast exhumation is likely in response to early Cenozoic deformation along tectonic boundary structures, related to the transpressional collision of the Indian plate with this region. Pre-Miocene episodes of fast exhumation corroborate recent paleoaltimetric studies, which show that the southeast margin of the Tibetan plateau was elevated prior to the Oligocene.

Keywords: southeast Tibet; Three Rivers region; low-temperature thermochronometry; exhumation; erosion rate 


\section{Introduction}

While much of the high-elevation, low-relief and internally-drained Tibetan Plateau is bounded by steep mountains, its southeast margin is characterized by a gradual topographic gradient where elevations descend from $4-5 \mathrm{~km}$ to $1-2 \mathrm{~km}$ over $1000-1500 \mathrm{~km}$. Three of the largest Asian rivers, the $\mathrm{Nu}$ (Salween), Lancang (Mekong), and Jinsha (Yangtze) rivers traverse the southeast margin, flowing roughly parallel to each other for hundreds of kilometers as they flow out of Tibet (Fig. 1). This area, the Three Rivers region, is characterized by deep incision separated by patches of relatively low relief highlands, which gradually become more continuous upstream and merge into the extensive low relief surfaces of the plateau interior.

Understanding the evolution of the Tibetan Plateau has great implications for both exploring the geodynamic processes of plateau growth and its potential link to changes in global climate (i.e., An et al., 2001; Roe et al., 2016; Royden et al., 1997; Tapponnier et al., 2001). The genesis of southeast margin's unique landscape and its geodynamic implications are debated, and two leading hypotheses have emerged (Clark et al., 2005; Liu-Zeng et al., 2008). One idea suggests that the gradual slope of Southeast Tibet is the result of ongoing crustal thickening due to lower crustal channel flow that initiated in the late Miocene (Clark and Royden, 2000; Royden et al., 1997). The other idea suggests that southeast Tibet attained its present height well before the mid-Miocene, was extruded along large strike-slip faults active during the early to mid-Cenozoic (Leloup et al., 1995; Lacassin et al., 1996; Tapponnier et al., 2001), and since then the plateau margin has undergone relief reduction and the retreat of the plateau margin via landscape lowering (e.g., Liu-Zeng et al., 2008). Yet another mechanism, autogenic stream piracy, was recently put forward as a means for building the unique topography of the southeast margin of Tibet during or after the plateau uplift (Yang et al., 2015). While each hypothesis is supported by a set of observations, a multiple low-temperature thermochronometer explanation of exhumation through time will help discriminating between them. 
A low-temperature thermochronometer records when a section of crust cooled through a closure temperature as it was exhumed towards the surface. A closely spaced vertical profile of cooling ages is commonly used to determine rates of exhumation. Because of their relatively low closure temperatures, apatite and zircon (U-Th)/He (AHe and $\mathrm{ZHe})$ and apatite fission track (AFT) analyses are the best tools in documenting the latest stages of the evolution of topography and cooling within the uppermost kilometers of the crust (Ehlers and Farley, 2003; Reiners and Brandon, 2006; Willett and Brandon, 2013).

Much of the support for the Miocene lower crustal flow hypothesis comes from previous low-temperature thermochronological studies in southeast Tibet (along the Yalong and Dadu rivers; Fig. 1b) that conclude that rapid exhumation since the late Miocene is reflected by increased river incision which began no earlier than 8-13 Ma (Clark et al., 2005; Ouimet et al., 2010). However, subsequent low-temperature thermochronometric data indicate Oligocene to early Miocene initiation of river incision (Shen et al., 2016; Tian et al., 2014), while Oligocene rapid exhumation has been identified in the Longmen Shan (Wang et al. 2012). In contrast, stable isotope paleoelevation studies suggest that the Three Rivers region has been at or near its present elevation since the Eocene (Hoke et al., 2014; Li et al., 2015; Tang et al., 2017), which lends supports to the extrusion and subsequent erosion hypothesis (Liu-Zeng et al., 2008). The apparent discrepancy between the rock uplift histories gleaned through low-temperature thermochronometry and paleoaltimetry highlights the need for additional data.

Earlier thermochronological studies typically applied AHe in the region east of the Three Rivers (Fig.1b) and extended their findings across the entire southeast plateau margin. Extrapolation of an exhumation history from a few localities to an entire region with a complex set of large strike-slip fault systems can be problematic because important regional differences and the potential for heterogeneities in exhumation history are not considered. Previous work in the Three Rivers region only sampled near the valley bottom (e.g., Yang et al., 2016); however, vertical transects that analyze multiple thermochronometers, are crucial to develop a comprehensive understanding of the regional uplift history. 
In this study, we apply low-temperature thermochronometric methods to 23 granitic samples collected at two nearly vertical profiles along the Lancang River at Deqin and Weixi (Figs. 2 and 3). Both profiles are composed of samples collected in close horizontal proximity to each other, and span a total relief of $2500 \mathrm{~m}$ for the Deqin transect $\left(\sim 28.5^{\circ} \mathrm{N}\right)$ and $1100 \mathrm{~m}$ for the Weixi transect $\left(\sim 27.5^{\circ} \mathrm{N}\right)$ (Fig. 2). We combine three thermochronometric systems (AHe, AFT, and ZHe) with closure temperatures ranging at $\sim 60-200^{\circ} \mathrm{C}$ (Farley, 2002; Laslett et al., 1987; Reiners, et al., 2004). Together, these systems allow us to reconstruct a continuous exhumation history from the mid-Cretaceous to present.

\section{Geologic Setting}

Most of the Three Rivers region is part of the Mesozoic Qiangtang terrane, bounded to the west by the Bangong-Nujiang suture, and to the east by the Jinsha suture and the Ailaoshan-Red River shear zone (Fig. 1; Chang and Zheng, 1973; Yin and Harrison, 2000). Further to the east is the Triassic Yidun arc (Fig. 1b). In central Tibet, the Qiangtang terrane trends east and is about $\sim 260 \mathrm{~km}$ wide, but in the Three Rivers region it gradually bends to the south and narrows to $\sim 50-100 \mathrm{~km}$ (Fig. 1a). Tertiary sedimentary rocks are scarce in Southeast Tibet, likely due to extensive erosion driven by the incision of large rivers (Fig. 1b). There are a series of isolated, elongated Tertiary basins, including the Yushu-Nangqian (Horton et al., 2002; Spurlin et al., 2005;), Gonjo (Studnicki-Gizbert et al., 2008;), Lanping, and Jianchuan basins (Gourbet et al., 2017; He et al., 1996; Hoke et al., 2014; Mou et al., 1999). Lower Tertiary sediments are restricted to the footwalls of the thrust faults that control the development of these narrow basins (Horton et al., 2002; Spurlin et al., 2005; StudnickiGizbert et al., 2008). Widespread Eocene to Oligocene igneous activity was largely coincident with early Tertiary basin development (Wang et al., 2001).

The Three Rivers region experienced prolonged orogenesis and hosts evidence for multiple phases of tectonic activity, from the archipelago orogenic stage of arc-arc and arccontinent subduction in the late Paleozoic-early Mesozoic, to continental subduction and collision in the late Mesozoic, and finally to intracontinental transpressional deformation by 
the Cenozoic (Tapponnier et al., 1986, 2001; Yin and Harrison, 2000; Pan et al., 2004; Morley et al., 2004). During the Cenozoic, the Three Rivers region has been subjected to oblique collision between India and Eurasia, and there is evidence for large-scale shortening, transpressional double thrusting, fault duplexing, strike-slip faulting and pull-apart basins (Lacassin et al., 1996; Pan et al., 2004; Tapponnier et al., 1986, 2001; Zhong et al., 2000). Quaternary tectonic activity in the region is mainly strike-slip in the north and transtensional in the south (Tapponnier et al., 1986, 2001; Wang et al., 1998).

The dominant structural fabric in the Three Rivers region is NS-oriented pervasive shearing. This is manifested as rhomb-shaped granitic bodies and elongate Tertiary basins, and by faults and shear zones, which all trend north-south (Fig. 1b). These large-scale shear zones include, from west to east: the Nujiang-Gaoligong, the Lancangjiang, and the Ailaoshan-Red River shear zones (Akciz et al., 2008; Leloup et al., 1995). The abnormal geometry of the $\mathrm{Nu}$ and Lancang basins (Hallet and Molnar, 2001; Fig. 1) is related to shortening and right-lateral shear between the northward moving Indian plate and South China Block (Tapponnier et al., 1986; Wang et al., 1998).

These rivers carve impressive, 2000-3000 m deep valleys as they flow out of the Tibetan plateau interior (Fig. 2), and leave perched patches of relatively flat surfaces in between (Clark et al., 2006; Liu-Zeng et al., 2008). These low-relief surfaces are developed in geologically diverse rock types with a wide range of ages, ranging from Triassic granite plutons to Jurassic-Cretaceous and Tertiary basins. The formation mechanisms responsible for these elevated low-relief surfaces, and their tectonic implications are the subject of considerable controversy (Clark et al., 2005; Liu-Zeng et al., 2008; Tian et al., 2014; Yang et al., 2015; Zhang et al., 2016).

\section{Sampling and methods}

\subsection{Sampling strategy}

To better understand the history of denudation in the region, we sampled vertical transects that maximized relief by spanning the high elevation, low-relief surfaces, to near the 
valley bottoms. We used three low-temperature thermochronometric systems, AHe, AFT and $\mathrm{ZHe}$, to explore the cooling history of these rocks and its relationship to topographic evolution. We targeted the Baima granitoid pluton for the Deqin transect and the Ludian pluton for the Weixi transect. Both plutons belong to the elongated N-S trending Jinshajiang orogenic belt, which is related to the closure of the Paleo-Tethyan ocean (Yin and Harrison, 2000; Pan et al., 2004; $\mathrm{Zi}$ et al., 2013). The granitoid batholiths were emplaced during the Permian-Triassic time, 255-240 Ma at Baima and 231-214 Ma at Ludian, respectively (Jian et al., 2003; Zi et al., 2013).

We collected a total of 23 granitoid samples from two transects near Deqin (DQ) and Weixi (WX), during two field seasons in 2009 and 2011 (Fig. 2; Table 1). Sampling in 2009 was conducted along major roads as a reconnaissance trip. In 2011, additional samples were collected, with a focus on vertical transects. To minimize the influence of topography on estimated exhumation rates, sampling for transects was limited to a $5 \mathrm{~km}$ horizontal radius (Braun, 2002). In the high-relief Deqin region, our sampling profile is composed of segments pieced together to overcome the rugged terrain and poor accessibility. Both the Deqin and Weixi transects are located on a steeper part of the topographic ramp from the interior of the plateau toward the southeast, as shown by the margin-parallel topographic swath profile (Fig. 2b). The Deqin transect spans the entire $2500 \mathrm{~m}$ relief of the ridge top to river bottom, whereas the Weixi transect covers 1100 m relief.

At Deqin, all but two of the samples were collected on the eastern bank of the Lancang River, within the Baima granitic pluton (Fig.3). The highest sample DQ11-01 is from 4794 masl., which is equivalent in elevation to the high-elevation and low-relief surfaces in this area (Fig. 2). Two lowermost samples were collected on the western bank of the Lancang river, with the lowest one (DQ11-20) at $2494 \mathrm{~m}$ asl. and $250 \mathrm{~m}$ above the Lancang River.

The Baima granitic pluton forms an N-S trending rhomb-shape, and is $25 \mathrm{~km}$ long and $17 \mathrm{~km}$ wide at its widest point. It is bound to the north by the Deqin-Zhongdian fault, and to the west by the Zigashi-Deqin fault, which is a NS-trending fault branching off the Jinsha Jiang fault zone that eventually connects with the Lancang Jiang fault zone (F2 in Figure 3a; 
Chen et al., 1987). The Zigashi-Deqin fault extends for over $800 \mathrm{~km}$, and generally dips 40$60^{\circ}$ west. Along this fault there are a series of Cenozoic basins, most prominently the Gongjo basin (Chen et al., 1987; Studnicki-Gizbert et al., 2008; Tang et al., 2017). The DeqinZhongdian fault shows evidence of Quaternary activity near Zhongdian, displaying both normal and right-lateral strike-slip motions (Chang et al., 2014).

At the Weixi transect, the sampled granite body of $100 \mathrm{~km}$ long by $10 \mathrm{~km}$ wide trends $\mathrm{N}-\mathrm{S}$, and is bounded by the Yangla fault to the east (F6 in Fig. 3c). This fault is part of the Jinsha Jiang fault zone and bounds the Tertiary Jianchuan basin. It merges with the WeixiQiaohou fault (F5 in Fig. 3c), which may be linked to the Ailaoshan-Red River fault (Chen et al., 1987; Leloup et al., 1995). The Jinsha Jiang fault zone is a deep-penetrating transpressive structure inherited from the suture-subduction zone, and has experienced poly-phased tectonic activities (Chen et al., 1987; Pan et al., 2004; Xu et al., 1992). The samples are located in an upper reach of a tributary of the Jinsha River. Two samples collected in 2009 (TL09-31 and TL09-30) are from the low-relief surface mapped by Clark et al. (2006) (Fig. 3c). The 2011 samples were collected within 8-10 km of each other (Figs. 3c and 3d). The local relief here is more subdued than near Deqin.

\subsection{Apatite and zircon analysis}

The low closure temperatures of apatite (U-Th)/He (AHe, $\sim 60 \pm 20^{\circ} \mathrm{C}$; Farley, 2002), apatite fission track (AFT, $\sim 110 \pm 20^{\circ} \mathrm{C}$; Laslett et al., 1987), and zircon (U-Th)/He (ZHe, $\sim 180 \pm 20^{\circ} \mathrm{C}$; Reiners et al., 2004) make it possible to measure cooling of the shallow crust that is too small in magnitude to be recorded by higher temperature systems in regions undergoing slow exhumation, and to offer more detailed information for very young cooling events or relief change (e.g., Ehlers and Farley, 2003; Farley, 2002; Braun, 2005). Recent studies have demonstrated that the accumulation of radiation damage may affect the $\mathrm{He}$ retentivity of apatite and zircon grains, and thus the closure temperature (Flowers, 2009; Guenthner et al., 2013). This effect can be manifested as a correlation between AHe and ZHe dates and the effective uranium concentration (eU) in suites of apatite or zircon grains (e.g., Flowers, 2009; Guenthner et al., 2013). 
All granitic samples targeted for ZHe or AHe or AFT were crushed and sieved following standard procedures, and zircon and apatite grains were separated to the $100-300 \mu \mathrm{m}$ fraction using heavy liquids. For AHe and ZHe dating, euhedral crystals were selected under a high power $(160 \times)$, polarized light stereo-zoom binocular microscope to detect the presence of potential small inclusions. Target crystals were measured and digitally photographed in at least two different orientations for $\alpha$-ejection corrections prior to analysis (Farley, 2002).

For samples collected in 2011, (U-Th)/He ages of apatite and zircon were measured with a Diode and a $\mathrm{CO}_{2}$ laser heater for $\mathrm{He}$ extraction, and a sector ICP-MS for U-Th determinations, at the University of Arizona. AHe and ZHe analysis of 2011 samples are single-grain measurements; each sample had, in general, three replicates, unless the quality of sample material did not yield sufficient grains. This measurement procedure is described in supplement S1, and raw data are listed in supplement Tables A1 and A2. For samples collected in 2009, (U-Th)/He ages of apatite were analyzed at the Centre de Recherches Petrographique et Geochimiques in Nancy, France. AHe analysis of 2009 samples was measured as multi-grain aliquots; each aliquot consisted of 6-10 inclusion-free grains. The procedure used for sample measurement is described in supplement S2 (Tibari et al., 2016), and these data are listed in the supplement Table A3.

Apatite fission track (AFT) analyses of all samples were conducted at the Neotectonic Geochronology Laboratory at the Institute of Geology, China Earthquake Administration. Experimental procedures are similar to that in Liu et al. (2013), as described in supplement S3. Apatite fission track data are listed in supplement Table A4.

\subsection{Calculation of exhumation and erosion rates}

Our samples were collected in close horizontal proximity along steep transects, and thus the age-elevation relationship can be used to derive rates of exhumation (e.g., Braun, 2005). Exhumation rates were calculated for two transects by considering $\mathrm{AHe}$, AFT and ZHe results separately (Fig. 5). Exhumation rates are quantified using the least-squares fitting of a straight line, with elevation as independent and thermochronometric age as dependent variables, weighted according to their uncertainties (Glotzbach et al., 2011). The weighted 
mean age calculations were made using Isoplot/Ex_ver3 (Ludwig, 2003).We also calculate erosions rate from the thermochronometric ages, following Willett and Brandon's (2013) analytical method. This method is based on the assumption of a constant rate of cooling, where the observed ages represent the time it takes a sample to travel from its closure depth to its modern elevation. With this model, a cooling age yields a time-averaged erosion rate for the corresponding thermochronometer of a given sample. The method assumes steadystate topography and that the thermal influence from topography is wavelength dependent (Braun, 2002), and is approximated through the calculation of a mean elevation.

To extract the erosion rate from a thermochronometric age, estimates of the modern geothermal gradient, time of initiation of erosion, and surface temperature are required. A local geothermal gradient is often assumed. But in this study, exhumation rate from vertical transects provide independent constraints on the current geothermal gradient. In addition, we set the initiation time of erosion to be the crystallization age of the granite we sampled. The surface temperature is assumed to be $5^{\circ} \mathrm{C}$. The radius of the elevation-averaging window is $5.6 \mathrm{~km}$ for the AHe, $10 \mathrm{~km}$ for the AFT, and $16 \mathrm{~km}$ for the ZHe. Yang et al. (2016) found that variations in the time of initiation of erosion and the size of the elevation-averaging window have small effects on the estimated erosion rate. The closure depths are determined by the geothermal gradient and the corresponding closure temperature. The closure temperature of $\mathrm{AHe}$ and $\mathrm{ZHe}$ is dependent on the amount of radiation damages accumulated (Flowers, 2009; Guenthner et al., 2013). Closure depth is relative to the mean elevation.

\subsection{Pseudo-elevation and age plots}

Reiners and Brandon (2006) introduced a stacked pseudo-elevation age profile that allows us to incorporate multiple thermochronometric age systems. The lowest temperature thermochronometer, AHe is, plotted against sample elevation, while other cooling ages are offset upward from their true elevations by a height equivalent to the difference in closure depth $(\mathrm{Zc})$ for that thermochronometer relative to $\mathrm{Zc}$ for the AHe system. In a minor departure from Reiners and Brandon (2006), we use the height above the closure depth of AHe, instead of the elevation of samples, which means a shift of the pseudo-elevation 
calculated with the method in Reiners and Brandon (200) by the amount of AHe closure depth, relative to the mean elevation of sampled vertical transect. In this definition, the pseudo-elevation of samples for each age group is equivalent to the height above the closure depth of the corresponding thermochronometer (AHe, AFT or ZHe). The closure depth is calculated based on assumed closure temperature for a specific thermochronometer, the geothermal gradient, and relative to the mean elevation of sampled vertical transect.

\section{Results}

Thirteen samples in the Deqin (DQ) spanning $2500 \mathrm{~m}$ to $5000 \mathrm{~m}$ elevation were analyzed for AHe, ZHe and AFT ages (Table 1 and supplement Tables A1, A2 and A4). Table 1 lists the weighted averages of $\mathrm{ZHe}$ and AHe ages. A total of ten single-grain and three multi-grain apatite samples yielded AHe ages ranging from 4 to 19 Ma. Single-grain zircon samples yielded ZHe ages from 79 to $111 \mathrm{Ma}$, except for the two lowermost samples,

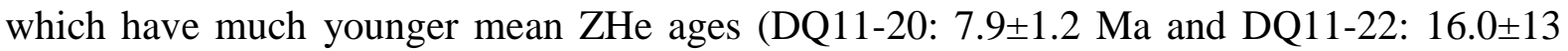
Ma). Multi-grain and single-grain analyses of apatite He from the two laboratories yield compatible ages. AFT ages of nine samples range from 15 to $57 \mathrm{Ma}$. The confined tracklength distributions are unimodal, and the mean track lengths are within $13.8-15.1 \mu \mathrm{m}$ (Supplement Table A4).

The Weixi (WX) transect consists of ten samples spanning $2298 \mathrm{~m}$ to $3420 \mathrm{~m}$ elevation (Table 1). Mean AHe ages for four single-grain samples and five multi-grain samples range from 15 to $65 \mathrm{Ma}$. Mean ZHe ages for five single-grain samples range from 88 to $122 \mathrm{Ma}$, except for one outlier, WX11-01 at $3420 \mathrm{~m}$, with an abnormally young age of 14.7 Ma. AFT ages of eight analyzed samples range from 53 to $116 \mathrm{Ma}$. Their mean track lengths cluster within 14.1-14.8 $\mu \mathrm{m}$ (Supplement Table A4).

In general, the Weixi transect yields older ages than the Deqin transect, but the difference is relatively small for ZHe ages and higher for AHe and AFT ages. For both transects, single-grain AHe and ZHe ages do not show clear relationships with the effective Uranium $([\mathrm{eU}]=[\mathrm{U}]+0.235 \times[\mathrm{Th}])$ contents, consistent with a no significant difference in 
He retentivity among grains with different amounts of radiation damage (Fig. 4). Two AHe grains of sample DQ11-20 yield abnormally old ages (60-70 Ma), which could potentially be explained with high eU content of 100-120 ppm. For each transect, AHe and ZHe ages increase with higher elevations; however, the Weixi transect shows a larger AHe age range than the Deqin transect, despite its shorter elevation span; 15-65 Ma over $850 \mathrm{~m}$ relief versus 4-19 Ma over $2000 \mathrm{~m}$ for Deqin (Fig. 5; Table 1). This suggests a lower rate in the exhumation through the top 2-3 $\mathrm{km}$ of the crust at Weixi.

We analyzed three samples for biotite ${ }^{40} \mathrm{Ar} /{ }^{39} \mathrm{Ar}$ ages, two from the Deqin transect and one from the Weixi (supplement Table A5). Biotite ${ }^{40} \mathrm{Ar} /{ }^{39} \mathrm{Ar}$ ages from the Deqin transect yield $226 \mathrm{Ma}$ and $250 \mathrm{Ma}$ respectively, and $217 \mathrm{Ma}$ from the Weixi transect. These ages are compatible, with fast cooling below $310 \pm 20{ }^{\circ} \mathrm{C}$ (Harrison et al., 1985), in association with emplacement of the Triassic pluton, rather than from exhumation-related cooling.

\section{Interpretations}

\subsection{Age-elevation relationships}

Exhumation rates are similar for all three thermochronometers in the Deqin transect (Fig. 5a). Regression through the AHe data indicates an exhumation rate of $177-250 \mathrm{~m} / \mathrm{Myr}$ from 20 until $4 \mathrm{Ma}$; similarly, AFT and ZHe ages indicate exhumation rates of $107 \mathrm{~m} / \mathrm{Myr}$ from 50-40 Ma and 144 m/Myr from 95-85 Ma, respectively. Samples collected in 2009 (unfilled symbols) are generally not used in calculating exhumation rate, except the ones adjacent to the 2011 sample transects and close enough to be considered part of the vertical profiles.

Note that elevation-age relationships of AFT and ZHe data in the Deqin transect show a sharp change below 3000-3500 $\mathrm{m}$ where sample ages become younger (Fig. 5a). The most dramatic difference is in the ZHe age distribution. The ZHe age of samples at $3000 \mathrm{~m}$ elevation and above are 80-100 Ma, whereas the two samples below $3000 \mathrm{~m}$ are 8-16 Ma. Offset in AFT data also occurs at the $\sim 3500$ m elevation level. The AFT ages of the samples $>=3500 \mathrm{~m}$ are $39-57 \mathrm{Ma}$, whereas the two samples at $\sim 3000 \mathrm{~m}$ and $2800 \mathrm{~m}$ are 15-21 Ma. For the low elevation samples, ZHe ages fall in the same range as the AFT ages. No such 
offset has been observed in AHe data, except for a small shift, 6 Ma, between the trend above $4500 \mathrm{~m}$ and that below $4200 \mathrm{~m}$. Thus, the vertical transect of $2500 \mathrm{~m}$ elevation span in our study clearly shows the divergence in ZHe and AFT ages between samples above and below $\sim 3000 \mathrm{~m}$. As will be discussed in the following section, the samples near the river bottom are closer to the Lancang Jiang fault zone and thus record the activity of this shear zone.

Exhumation rates from the Weixi transect are less well defined than those from the Deqin transect (Fig. 5b). Regression through the AHe data shows an exhumation rate of 76 $\mathrm{m} / \mathrm{Myr}$ between 30 and $50 \mathrm{Ma}$; similarly, AFT ages have an exhumation rate of $16 \mathrm{~m} / \mathrm{Myr}$ between 50 and $100 \mathrm{Ma}$. However, ZHe ages of all samples are nearly identical between110 and $120 \mathrm{Ma}$. In the Weixi transect, AHe and AFT age results of the 2009 samples show more disparate age-elevation pattern. Except for sample TL09-27 $(2300 \mathrm{~m})$, the remaining four multi-grain samples show a significant deviation. The 2009 samples were not considered in the calculation of exhumation rate.

\subsection{Pseudo-elevation and age relationships}

We plot cooling ages from Deqin and Weixi transects as modified pseudo-elevation age profile, where the pseudo-elevation of samples refers to the height above the closure depth of the corresponding thermochronometer (AHe, AFT or $\mathrm{ZHe}$ ), relative to the mean elevation of the sample transect (Fig. 6). We use a geothermal gradient of $30{ }^{\circ} \mathrm{C} / \mathrm{km}$ when calculating the closure depth. The geothermal gradient is similar to that implied by Willett and Brandon (2013)'s analytical method, based on age constraints of multiple samples in vertical transects (Fig. 7). The latter gives a reasonable estimate of the average thermal state during cooling, even though some variability through time is suggested, as the sample age curves do not generally intersect (Fig.7).

The pseudo-elevation age plot shows that the Deqin pluton experienced three major phases of rapid exhumation, 220-650 m/Myr from $20 \mathrm{Ma}$ until present, $600 \mathrm{~m} / \mathrm{Myr}$ at $40 \mathrm{Ma}$, and a moderate rate of $\sim 145 \mathrm{~m} / \mathrm{Myr}$ from 100-80 Ma. Between these phases are periods (20 to $40 \mathrm{Ma}$; 50-80 Ma) of very slow exhumation, $\sim 30 \mathrm{~m} / \mathrm{Myr}$. Three phases of fast exhumation 
are consistent with the age-elevation relationship shown in Fig. 5a. The latest phase of fast exhumation initiated circa $20 \mathrm{Ma}$ and has been sustained at a roughly constant rate until $\sim 4-5$ Ma, since when there is a possible acceleration of up to $650 \mathrm{~m} / \mathrm{Myr}$. The Eocene phase of fast exhumation was short, but is clearly distinguishable. The Late Cretaceous phase of fast exhumation lasted for at least $20 \mathrm{Ma}$.

Similarly, the Weixi transect reveals three phases of fast exhumation, $\sim 80 \mathrm{~m} / \mathrm{Myr}$ since $\sim 18 \mathrm{Ma}$ and $\sim 356 \mathrm{~m} / \mathrm{Myr}$ from 50 to $60 \mathrm{Ma}$, and $\sim 1366 \mathrm{~m} / \mathrm{Myr}$ from 130-115 Ma, separated by periods of very slow exhumation, $\sim 18 \mathrm{~m} / \mathrm{Myr}$ from 115-60 Ma and from 50-20 Ma (Fig. 6b). The latest phase of fast exhumation is bounded by sample TL09-27, which has been exhumed $\sim 1.3 \mathrm{~km}$ since $\sim 16 \mathrm{Ma}$, with an exhumation rate of $80 \mathrm{~m} / \mathrm{Myr}$. This rate is four times faster than that from $50-20 \mathrm{Ma}(\sim 18 \mathrm{~m} / \mathrm{Myr})$. The initiation time of this latest phase is not well constrained, due to a lack of samples at lower elevations as a result of the relatively low local relief. The second latest phase of fast exhumation occurred in the Paleocene from 50 to $60 \mathrm{Ma}$. The Paleocene-Eocene exhumation events are similar at both studied locations. Both are of short durations and with $\sim 1-1.5 \mathrm{~km}$ of exhumation. The Cretaceous phase of exhumation at Weixi lasted until $\sim 115 \mathrm{Ma}$, earlier than the exhumation at Deqin.

\subsection{Average erosion rates from AHe, AFT and ZHe ages}

Figure 7 shows the erosion rates calculated for the Deqin and Weixi transects, using the method by Willett and Brandon (2013) to convert these cooling ages to erosion rates. Erosion rate is a function of geothermal gradient, which is often unknown. Here, we assume a geothermal gradient similar to that used in previous studies (Tian et al., 2014; Clark et al., 2005; Yang et al., 2016; Zhang et al., 2016). Under geothermal gradients ranging from 25 $40^{\circ} \mathrm{C} / \mathrm{km}$, erosion rates at Deqin are $40-90 \mathrm{~m} / \mathrm{Myr}$ from $\mathrm{ZHe}$ data, increase to 60 - 380 m/Myr from AFT, and 100 - 550 m/Myr from AHe (Figs. 7a, 7b, and 7c). Samples from high elevations yield lower erosion rates than those from low elevations. As shown in Fig. 7a, the erosion rate calculated from AHe age ranges between 100 and $200 \mathrm{~m} / \mathrm{Myr}$ for samples above $4500 \mathrm{~m}$ asl., while increasing to 200 to $550 \mathrm{~m} / \mathrm{Myr}$ for those below $4200 \mathrm{~m}$. Similarly, the erosion rate calculated from AFT ages shows that samples below $3300 \mathrm{~m}$ asl. yield values 
two to three times larger than those above. Near valley bottom samples yield ZHe agederived erosion rates ten-fold larger than those at ridge top. Similary, Yang et al (2016) reported high erosion rate, up to $1000 \mathrm{~m} / \mathrm{Myr}$, for their samples along valley bottom near Deqin. One possibility to explain the divergence in erosion rate for valley-bottom and ridgetop samples (such as 11-01, 11-03, and 11-04) is that the latest phase of fast exhumation was not "felt" by high-elevation samples. Alternatively, the mean erosion rate calculated using Willett and Brandon (2013) could be an over-estimate for samples near the Lancang river bottom. The overestimation may result from not taking into account fully the consequence of the isotherms being compressed towards the bottom of the river valley (e.g., Stüwe et al., 1994).

At Weixi, if assuming a loosely constrained, constant geothermal gradient of 20$30^{\circ} \mathrm{C} / \mathrm{km}$, erosion rates would be $40-100 \mathrm{~m} / \mathrm{Myr}$ from $\mathrm{ZHe}, 18-85 \mathrm{~m} / \mathrm{Myr}$ from AFT and 18-55 m/Myr from AHe (Figs. 7d-7f). The average erosion rate at Weixi appears to stay nearly constant, with arguably a trend of decrease over time. The most striking difference between Weixi and Deqin sites is recorded in the AHe data, which shows much slower exhumation in Weixi.

In comparison, three approaches of interpreting thermochronometric data provide slightly different and complimentary information about the exhumation history. Elevation versus age relationship of the vertical profiles show the exhumation rate over segmented periods covered by sample age ranges. Pseudo-elevation and age relationship, by stacking different thermochronometric ages in one single profile, provides additional information in the timing of "break-in-slope". This would affect the choice of samples in least-squares line fitting, thus change slightly the number of best-fitting exhumation rate. The method of converting thermochronometric ages to erosion rates developed by Willett and Brandon (2013) yields an average rate of rock traveling from the closure depth to the surface. It is equivalent to the average rate in the path shown in the pseudo-elevation and age plot.

\subsection{Tectonic control on the exhumation of the Three Rivers region}


The exhumation history revealed by the Deqin and Weixi transects share some common features in temporal variation but differ in the magnitude of the exhumation rate. Both transects show three phases of fast exhumation, Cretaceous, Paleocene-Eocene, and Miocene to recent. The amount of exhumation at Deqin is greater than that at Weixi. For instance, since $40 \mathrm{Ma}$ there has been $\sim 4 \mathrm{~km}$ of exhumation at Deqin and $\sim 1.5 \mathrm{~km}$ at Weixi.

Regional tectonic activity provides important information for interpreting the exhumation history at the regional scale. The Deqin and Weixi transects, separated by $\sim 150$ $\mathrm{km}$, are both within the Qiangtang terrane and may have experienced a similar tectonic history (Figs. 8 and 9).

The Three Rivers region has experienced various tectonic regimes from the Mesozoic through the Cenozoic (e.g., Chen et al., 1987; Metcalf, 2006; Pan et al., 2004). The Cretaceous phase of fast exhumation revealed at Deqin and Weixi probably corresponds to the continental collision between the Lhasa and Qiangtang terranes along the BangongNujiang suture zone, related to the closure of the Tethyan and eastward over-thrusting of the Lhasa terrane along the Nujiang suture. The timing of fast exhumation is slightly different, 80-100 Ma at Deqin and >115-130 Ma at Weixi. This difference may be due to deformation switching between parallel faults (Fig. 9).

In response to the oblique collision of India and Eurasia in the Three Rivers region during the Cenozoic period, transpressional structures progressively evolved into shears zones and extrusions, as the Indian plate pushed its way further north. Large-scale thrusting and structural duplexing during the early Cenozoic (the Paleocene and early Eocene) are documented as continental foreland basins, which formed thick molasse-type clastic deposits from the late Eocene and Oligocene (He et al., 1996; Mou et al., 1999; Pan et al., 2004). The early Cenozoic phase of deformation is poorly documented because shearing and strike-slip faulting obscure earlier phases of deformation and there is also a lack of preserved Cenozoic sediments, due to pervasive erosion. In the basins where Cenozoic sediments are preserved, previous studies documented significant syncollisional shortening based on detailed geological mapping of the nearby Nangqian-Yushu thrust belt (Spurlin et al., 2005). 
The fast exhumation in the Eocene revealed at both Deqin and Weixi is possibly in response to early Cenozoic deformation (Fig. 9). The Weixi site is located 10-20 km east of the Yangla fault, a branch of the Jinsha Jiang fault zone; whereas the Deqin site is $10-15 \mathrm{~km}$ from Zigashi-Deqin fault, which is also a splay of the Jinsha Jiang fault zone (Figs. 3, 8 and 9). Both are major Cenozoic west-dipping reverse fault systems (Chen et al., 1987; Pan et al., 2004; Xu et al., 1992). The Zigashi-Deqin fault zone controls the development of the elongated Paleogene Gonjo basin in the footwall, which is filled with thick non-marine sediments synchronous with the early Tertiary shortening (Studnicki-Gizbert et al., 2008; Tang et al., 2017). Similarly, the Yangla fault constitutes the western basin-bounding reverse fault of the Paleocene-Eocene Jianchuan basin (Gourbet et al., 2017). Throughout east and southeast Tibet, samples located in the vicinity of currently active or Cenozoic-active faults tend to yield young ages, whereas the samples far from active structures yield older ages (Fig. 8; Cook et al., 2013; Godard et al., 2009; Tian et al., 2013; Wang et al., 2012; Zhang et al., 2016). Higher exhumation rates and greater tectonic uplift is localized along tectonic boundaries. If so, slower exhumation rate at the Weixi transect may suggest less activity of the Yangla fault or a larger distance from the sampling site to the fault, as compared to the Zigashi-Deqin fault near the Deqin transect. The difference in the timing of initiation of Paleogene rapid exhumation at our two sampling sites, i.e., 50-60 Ma at the Weixi transect, and 40-45 Ma at Deqin, is probably an indication of the reactivation of individual structures, and the migration of activity within a fault zone (Fig. 9). Note that our interpretation of the thermal history thus far is general and simplistic. Quantification of the kinematics of deformation from exhumation history would require a more sophisticated thermo-kinematic modeling that take into account of isotherm advection during exhumation, relief change, and other factors (e.g., Braun, 2002; Ehlers and Farley, 2003; Robinson et al., 2010).

The latest phase of fast exhumation following the Late Miocene is well documented in eastern Tibet, starting at 10-15 Ma (Clark et al., 2005; Godard et al., 2009; Ouimet et al., 2010; Wang et al., 2012; Zhang et al., 2016), although recent studies suggested an earlier, Oligocene-Miocene initiation time in southeast Tibet (Shen et al., 2016; Tian et al., 2014). 
The pluton near Deqin has been eroding 2-9 times faster than that near Weixi over the last 15 Ma (Fig. 6), which is similar to the relative difference in erosion rates between the Lancang and Jinsha rivers, calculated by Yang et al. (2016). The Deqin transect is located on the Lancang river, whereas the Weixi transect is on the upper reach of a tributary of the Jinsha river. The eastbound decrease in ${ }^{10} \mathrm{Be}$-derived millennium time-scale erosion rate from the Lancang to Jinsha drainage basins (Henck et al., 2010), suggests that the spatial difference between drainage basins has continued to the present. $1300 \mathrm{~m}$ of erosion since 16 Ma has taken place at Weixi and is similar to the amount of incision near the first bend of the Jinsha River constrained by cosmogenic burial ages of cave deposits (McPhillips et al., 2016).

\section{Discussion}

Two phases of fast exhumation in the Cenozoic are documented to the east, in the Yalong river drainage (Zhang et al., 2016) and in the Longmen Shan (Wang et al., 2012). Our results support previous speculation that early to middle Cenozoic deformation was more widespread and variable within southeast Tibet than previously thought (Liu-Zeng et al., 2008; Zhang et al., 2016).

Studies showing two phases of fast exhumation in the Cenozoic share a common feature in that the sampled transects are within or close to large-scale geological structures (Figs. 8 and 9). In the Three Rivers region, our two sample sites are within 10-20 $\mathrm{km}$ of the Jinsha Jiang fault zone, a major structure of the Qiangtang terrane. In the Yalong Jiang drainage, profiles sampled by Zhang et al. (2016) are within $40 \mathrm{~km}$ of, and on the hanging wall of the Yunongxi reverse fault, which is one of the three major faults of the Yalong-Yulong thrust fault zone (BGMR Sichuan, 1991; Deng et al., 2003). Similarly, Wang et al. (2012) sampled the hanging wall of the Longmen Shan fold and thrust belt. Thus, exhumation from lowtemperature thermochronometric data reveals the tectonic activity of individual structures near the sampling sites. Profiles sampled far from active geologic structures do not show evidence for two phases of rapid Cenozoic exhumation (e.g., Tian et al., 2014; Ouimet et al., 2010), nor do samples collected at low elevations and/or low elevation samples that were not 
analyzed for multiple thermochronometers (Yang et al., 2016; Godard et al., 2009; Clark et al., 2005).

Our multiple thermochronometers results that reveal episodes of rapid exhumation during the Eocene and Cretaceous are compatible with recent paleoaltimetric results on preMiocene high topography in southeast Tibet (Hoke et al., 2014; Li et al., 2015; Tang et al., 2017). The Paleogene plateau may have been continuous from central Tibet, and extended southeastward to at least $25-26^{\circ} \mathrm{N}$ (Hoke et al., 2014). Early Tertiary tectonism in the region revealed by our low-temperature thermochronometric data provides a geologic context for the increase of high topography in southeast Tibet prior to the late-Miocene. It allows for the possibility that residual topography from the mid- to late- Cretaceous phase of terrane accretion and continental collision have also contributed to regionally high topography.

The exhumation history revealed in this study also sheds light on how to interpret areas of subdued relief between deeply-incised river valleys (Clark et al., 2006; Liu-Zeng et al., 2008). It has been proposed that these high-elevation, low-relief surfaces developed at low elevations by lowland rivers before subsequent uplift by the outward flow of thick lower crust from central Tibet (Clark et al., 2006). This interpretation hinges on two important assumptions: 1) the surface had undergone a protracted period of slow cooling before uplift, and 2) erosion rates are slow enough to allow the surfaces to be used as a proxy for elevation change. However, in the Three Rivers region, the punctuated phases of tectonism from Cretaceous to early Tertiary deviate from the tectonic quiescence required for this model. Furthermore, the highest sample (4974 m) at Deqin suggests $\sim 5.7 \mathrm{~km}$ rock eroded since 57 Ma. This implies 1.5-2.5 $\mathrm{km}$ erosion since 13-8 Ma, the presumed onset of regional surface uplift and the abandonment of the low-relief surface. With this magnitude of erosion and spatially heterogeneous exhumation, an uplifted low-relief surface would have experienced significant modification to now form a single continuous surface.

\section{Conclusion}


We provide new constraints on the long-term exhumation and river incision histories in

527

528

529

530

531

532

533

534

535

536

537

538

539

540

541

542

543

544

545

546

\section{Acknowledgement}

548

549

550

551 surface uplift before Miocene. the Three Rivers region, SE Tibet, using apatite and zircon (U-Th)/He (AHe and ZHe) and apatite fission track (AFT) thermochronometry. We sampled vertical profiles near Deqin $\left(\sim 28.5^{\circ} \mathrm{N}\right)$ and Weixi $\left(\sim 27.5^{\circ} \mathrm{N}\right)$, with an elevation span of $2500 \mathrm{~m}$ and $1100 \mathrm{~m}$, respectively, and the highest samples on or close to high-elevation, low-relief surfaces. The Deqin transect is on the Lancang trunk river, whereas the Weixi profile is in the headwaters of a tributary of the Jinsha river. We found that two profiles share a similar exhumation history: two episodes of relatively fast exhumation in the Cenozoic, $\sim 100-300 \mathrm{~m} / \mathrm{Myr}$ during the Paleocene-Eocene (60-40 Ma) and from the Miocene to present (20-0 Ma). An earlier episode of moderate exhumation also occurred during the middle to late Cretaceous (120-80 Ma). Erosion during the last 10-20 Ma is of both a higher magnitude and a faster rate at Deqin than at Weixi. This is consistent with previous studies showing the relative difference in incision rates between the Lancang and Jinsha rivers. Furthermore, samples near the Lancang river bottom at Deqin show faster exhumation than those at ridge-top during the 0-20 Ma period. The Cretaceous phase of rapid exhumation was not reported in previous low-temperature thermochronological studies. The early Cenozoic phase of fast exhumation was reported in the region to the east, but occurred earlier in time in the Three Rivers region. Eocene rapid exhumation is likely a thermal response of early Cenozoic deformation along tectonic boundary structures, providing geological support to recent paleoaltimetric studies suggesting

This study was supported by the National Key Research and Development Project of China (2016YFC0600310), National Natural Science Foundation of China (41225010, 41502188), and State Key Laboratory of Earthquake Dynamics (LED2014A02). We thank Junjie Yu and Ze Su for their assistance in the field, Rong Yang, Huiping Zhang and An Yin 


\section{References}

An, Z., Kutzbach, J.E., Prell, W.L., et al., 2001. Evolution of Asian monsoons and phased uplift of the Himalaya-Tibetan plateau since late Miocene times. Nature 411, 62-66.

Akciz, S., Burchfiel, B.C., Crowley, J.L., Jiyun, Y., Liangzhong, C., 2008. Geometry, kinematics, and regional significance of the Chong Shan shear zone, Eastern Himalayan Syntaxis, Yunnan, China. Geosphere 4, 292-314.

Braun, J., 2002. Estimating exhumation rate and relief evolution by spectral analysis of age-elevation datasets. Terra Nova 14, 210-214.

Braun, J., 2005. Quantitative constraints on the rate of landform evolution derived from low-temperature thermochronology. Reviews in Mineralogy and Geochemistry 58, 351-374.

Brozović, N., Burbank, D. W., Meigs, A. J., 1997, Climatic limits on landscape development in the northwestern Himalaya. Science 276(5312), 571-574.

Chang C-F, Zheng.S.-L., 1973. Tectonic features of the Mount Jolmo Lungma region in southern Tibet, China. Scientia Geologica Sinica 1, 1-12.

Chang Z.F., Zhang, Y. F., Li, J. L., and Zang, Y., 2014, The Geological and geomorphic characteristic of late Quaternary activity of the Deqin-Zhongdian-Daju fault. Journal of Seismological Research, 37(1):46-52.

Chen B.W., Wang, K. Y., Liu, W. X., Cai, Z.J., Zhang, Q. W., Peng, X. J., Qiu, Y. Z., Zheng, Y.Z., et al. (ed.), 1987. Geotectonics of the Nujiang-Lancang Jing-Jinsha Jiang region. Geological Press, Beijing. pp. 206.

Clark, M.K., House, M., Royden, L., Whipple, K., Burchfiel, B., Zhang, X., Tang, W., 2005. Late Cenozoic uplift of southeastern Tibet. Geology 33, 525-528.

Clark, M., Royden, L., Whipple, K., Burchfiel, B., Zhang, X., Tang, W., 2006. Use of a regional, relict landscape to measure vertical deformation of the eastern Tibetan Plateau. Journal of Geophysical Research: Earth Surface (2003-2012) 111.

Cook, K., Royden, L., Burchfiel, B., Lee, Y.-H., Tan, X., 2013. Constraints on Cenozoic tectonics in the southwestern Longmen Shan from low-temperature thermochronology. Lithosphere 5, 393-406.

Deng, Q., Zhang, P., Ran, Y., Yang, X., Min, W., Chu, Q., 2003. Basic characteristics of active tectonics of China. Science in China Series D: Earth Sciences 46, 356-372.

Ehlers, T.A., Farley, K.A., 2003. Apatite (U-Th)/He thermochronometry: methods and applications to problems in tectonic and surface processes. Earth \& Planetary Science Letters 206, 1-14.

Farley, K.A., 2002. (U-Th)/He Dating: Techniques, Calibrations, and Applications. Reviews in Mineralogy \& Geochemistry 47, 819-844.

Flowers, R., 2009. Exploiting radiation damage control on apatitite (U-Th/He) dates in cratonic regions. Earth and Planetary Science Letters 277, 148-155.

Glotzbach, C., van der Beek, P. A., Spiegel, C., 2011. Episodic exhumation and relief growth in the Mont Blanc massif, Western Alps from numerical modelling of thermochronology data. Earth \& Planetary Science Letters 304(3-4):417-430.

Godard, V., Pik, R., Lavé, J., Cattin, R., Tibari, B., De Sigoyer, J., Pubellier, M., Zhu, J., 2009. Late Cenozoic evolution of the central Longmen Shan, eastern Tibet: insight from (U - Th)/He thermochronometry. Tectonics 28.

Gourbet, L., Mahéo, G., Leloup, P.H., Jean-Louis, P., Sorrel, P., Eymard, I., Antoine, P-O., Sterb, M., Wang, G., Cao, K., Chevalier, M., Lu, H., 2017. Reapprisal of the Jianchuan Cenozoic basin stratigraphy and its implications on the SE Tibetan Plateau evolution. Tectonophysics, doi: 10.1016/j.tecto.2017.02.007

Guenthner W R, Reiners P W, Ketcham R A, Nasdala, L., Giester, G., 2013. Helium diffusion in natural zircon: Radiation damage, anisotropy, and the interpretation of zircon (U-Th)/He thermochronology. American Journal of Science 313,145-198.

Hallet, B., Molnar, P., 2001. Distorted drainage basins as markers of crustal strain east of the Himalaya. J. Geophys. Res. 106, 13697-13709. 
Harrison, T.M., Duncan, I., McDougall, I., 1985. Diffusion of 40 Ar in biotite: temperature, pressure and compositional effects. Geochimica et Cosmochimica Acta 49, 2461-2468.

He, K., He, H., Cai, H.B., 1996. Formation and evolution of the western Yunnan orogenic belt. Geological Review 42(2), 97-106 (in Chinese with English abstract).

Hoke, G.D., Liu-Zeng, J., Hren, M.T., Wissink, G.K., Garzione, C.N., 2014. Stable isotopes reveal high southeast Tibetan Plateau margin since the Paleogene. Earth and Planetary Science Letters 394, 270278.

Horton, B.K., Yin, A., Spurlin, M.S., Zhou, J., Wang, J., 2002. Paleocene-Eocene syncontractional sedimentation in narrow, lacustrine-dominated basins of east-central Tibet. Geological Society of America Bulletin 114, 771-786.

Jian, P., Liu, D., and Sun, X., 2003. SHRIMP dating of Baimaxueshan and Ludian granitoid batholiths, northwestern Yunnan Province, and its geological implications. Acta Geologica Sinica 24,337-342.

Lacassin, R., Schärer, U., Leloup, P.H., Arnaud, N., Tapponnier, P., Liu, X., Zhang, L., 1996. Tertiary deformation and metamorphism SE of Tibet: The folded Tiger - leap décollement of NW Yunnan, China. Tectonics 15, 605-622.

Laslett, G.M., Green, P.F., Duddy, I.R., Gleadow, A.J.W., 1987. Thermal annealing of fission tracks in apatite 2. A quantitative analysis. Chemical Geology Isotope Geoscience 65, 1-13.

Leloup, P.H., Lacassin, R., Tapponnier, P., Schaerer, U., Zhong, D., Liu, X., Zhang, L., Ji, S., Trinh, P.T., 1995. The Ailao Shan-Red River shear zone (Yunnan, China), Tertiary transform boundary of Indochina. Tectonophysics 251, 3-84.

Li, S., Currie, B.S., Rowley, D.B., Ingalls, M., 2015. Cenozoic paleoaltimetry of the SE margin of the Tibetan Plateau: Constraints on the tectonic evolution of the region. Earth \& Planetary Science Letters 432, 415-424.

Li, H., Zhang, Y., 2013. Zircon U-Pb geochronology of the Konggar granitoid and migmatite: constraints on the Oligo-Miocene tectono-thermal evolution of the Xianshuihe fault zone, East Tibet. Tectonophysics 606, 127-139.

Liu J., Zhang, P., Lease, R. O., et al., 2013. Eocene onset and late Miocene acceleration of Cenozoic intracontinental extension in the North Qinling range-Weihe graben: Insights from apatite fission track thermochronology. Tectonophysics 584, 281-296.

Liu-Zeng, J., Tapponnier, P., Gaudemer, Y., Ding, L., 2008. Quantifying landscape differences across the Tibetan plateau: Implications for topographic relief evolution. Journal of Geophysical Research: Earth Surface (2003-2012) 113.

Ludwig, K., 2003. User's manual for Isoplot 3.00: a geochronological toolkit for Microsoft Excel. Kenneth R. Ludwig.

McPhillips, D., Hoke, G.D., Liu-Zeng, J., Bierman, P.R., Rood, D.H., Niedermann, S., 2016. Dating the incision of the Yangtze River gorge at the First Bend using three - nuclide burial ages. Geophysical Research Letters 43, 101-110.

Metcalfe, I., 2006. Palaeozoic and Mesozoic tectonic evolution and palaeogeography of East Asian crustal fragments: the Korean Peninsula in context. Gondwana Research 9, 24-46.

Morley, C. K., 2004. Nested strike-slip duplexes, and other evidence for Late Cretaceous-Palaeogene transpressional tectonics before and during India-Eurasia collision, in Thailand, Myanmar and Malaysia. J Geol Soc London, 2004, 161: 799-812.

Mou, C. Wang, J., Yu, Q., Zhang L., 1999. The evolution of the sedimentary basin in Lanping area during Mesozoic-Cenozoic. J. Mineral and Petrology 19 (3), 30-36.

Ouimet, W., Whipple, K., Royden, L., Reiners, P., Hodges, K., Pringle, M., 2010. Regional incision of the eastern margin of the Tibetan Plateau. Lithosphere 2, 50-63.

Pan, Wang, L., Zhu, D., 2004. Thoughts on some important scientific problems in regional geological survey of the Qinghai-Tibet Plateau Geological bulletin of China 23, 12-19.

Reiners, P.W., Brandon, M.T., 2006. Using thermochronology to understand orogenic erosion. Annu. Rev. Earth Planet. Sci. 34, 419-466.

Reiners, P.W., Spell, T.L., Nicolescu, S., Zanetti, K.A., 2004. Zircon (U-Th)/He thermochronometry: He diffusion and comparison with 40Ar/39Ar dating. Geochimica et Cosmochimica Acta 68, 1857-1887.

Robinson, A.C., Yin, A., Lovera, O.M., 2010. The role of footwall deformation and denudation in controlling cooling age patterns of detachment systems: An application to the Kongur Shan extensional system in the Eastern Pamir, China. Tectonophysics 496:28-43. 
Roe, G.H., Ding, Q.H., Battisti, D.S., Molnar, P., Clark, M.K., Garzione, C.N., 2016. A modeling study of the response of Asian summertime climate to the largest geologic forcings of the past $50 \mathrm{Ma}$. J. Geophys. Res.-Atmos. 121, 5453-5470.

Royden, L.H., Burchfiel, B.C., King, R.W., Wang, E., Chen, Z., Shen, F., Liu, Y., 1997. Surface deformation and lower crustal flow in eastern Tibet. Science 276, 788-790.

Shen, X., Tian, Y., Li, D., Qin, S., Vermeesch, P., Schwanethal, J., 2016. Oligocene-Early Miocene river incision near the first bend of the Yangze River: Insights from apatite (U-Th-Sm)/He thermochronology. Tectonophysics 687, 223-231.

Spurlin, M.S., Yin, A., Horton, B.K., Zhou, J., Wang, J., 2005. Structural evolution of the Yushu-Nangqian region and its relationship to syncollisional igneous activity, east-central Tibet. Geological Society of America Bulletin 117, 1293-1317.

Stüwe, K., White, L., Brown, R., 1994. The influence of eroding topography on steady-state isotherms. Application to fission track analysis. Earth and Planetary Science Letters 124, 63-74.

Studnicki-Gizbert, C., Burchfiel, B., Li, Z., Chen, Z., 2008. Early Tertiary Gonjo basin, eastern Tibet: Sedimentary and structural record of the early history of India-Asia collision. Geosphere 4, 713-735.

Tang, M., Liu-Zeng, J., Hoke, G., Xu, Q., Li, Z., Wang, W., 2017. Paleoelevation reconstruction of the Paleocene-Eocene Gonjo basin, SE-central Tibet, Tectonophysics, in revision.

Tapponnier, P., Peltzer, G. \& Armijo, R. 1986. On the mechanism of collison between India and Asia. In: Coward, M.P. \& Ries, A.C. (eds) Collision Tectonics. Geological Society, London, Special Publications, 19, 115-157.

Tapponnier, P., Zhiqin, X., Roger, F., Meyer, B., Arnaud, N., Wittlinger, G., Jingsui, Y., 2001. Oblique stepwise rise and growth of the Tibet Plateau. Science 294, 1671-1677.

Tian Y., Kohn B. P, Gleadow, A. J. W., Hu, S., 2013. Constructing the Longmen Shan eastern Tibetan Plateau margin: Insights from low-temperature thermochronology. Tectonics 32, 576-592.

Tian,Y., Kohn, B.P., Gleadow, A.J., Hu, S., 2014. A thermochronological perspective on the morphotectonic evolution of the southeastern Tibetan Plateau. Journal of Geophysical Research: Solid Earth.

Tian, Y., Kohn, B.P., Hu, S., Gleadow, A. J. W., 2015. Synchronous fluvial response to surface uplift in the eastern Tibetan Plateau: implications for crustal dynamics. Geophys. Res. Lett. 42, 2014 GL062383.

Tibari, B., Vacherat, A., Stab, M., Pik, R., Yeghicheyan, D., Hild. P., 2016. An alternative protocol for single zircon analysis by ICP-MS. Geost. Geoan. Res. doi: 10.1111/j.1751-908X.2016.00375.x.

Wang, E., Burchfiel, B.C., Royden, L.H., Chen, L., Chen, J., Li, W., Chen, Z., 1998. Late Cenozoic Xianshuihe-Xiaojiang, Red River, and Dali fault systems of southwestern Sichuan and central Yunnan, China. Geological Society of America Special Papers 327, 1-108.

Wang, E., Kirby, E., Furlong, K.P., Van Soest, M., Xu, G., Shi, X., Kamp, P.J., Hodges, K., 2012. Twophase growth of high topography in eastern Tibet during the Cenozoic. Nature geoscience 5, 640-645.

Wang, J.-H., Yin, A., Harrison, T. M., Grove, M., Zhang, Y.-Q., Xie, G.-H. 2001. A tectonic model for Cenozoic igneous activities in the eastern Indo-Asian collision zone, Earth Planet. Sci. Lett., 188(1), 123-133.

Willett, S.D., Brandon, M.T., 2013. Some analytical methods for converting thermochronometric age to erosion rate. Geochemistry, Geophysics, Geosystems 14, 209-222.

Wilson, C.J., Fowler, A.P., 2011. Denudational response to surface uplift in east Tibet: Evidence from apatite fission-track thermochronology. Geological Society of America Bulletin 123, 1966-1987.

Xu, Z.Q., Hou, L. W., Wang, Z.X., Hu, X.F., Huang, M.H., 1992. Orogenic Processes of the SongpanGarzê Orogenic Belt of China, 190 pp., Geological House, Beijing.

Yang, R., Willett, S.D., Goren, L., 2015. In situ low-relief landscape formation as a result of river network disruption. Nature 520, 526-529.

Yang, R., Fellin, M.G., Herman, F., Willett, S.D., Wang, W., Maden, C., 2016. Spatial and temporal pattern of erosion in the Three Rivers Region, southeastern Tibet. Earth Planetary Science Letters 433, 10-20.

Yin, A., Harrison, T.M., 2000. Geologic evolution of the Himalayan-Tibetan orogen. Annual Review of Earth and Planetary Sciences 28, 211-280.

Zhang, H., Oskin, M.E., Liu-Zeng, J., Zhang, P., Reiners, P.W., Xiao, P., 2016. Pulsed exhumation of interior eastern Tibet: Implications for relief generation mechanisms and the origin of high-elevation planation surfaces. Earth \& Planetary Science Letters 449, 176-185.

Zhang, Y.-Z., Replumaz, A., Wang, G.-C., Leloup, P.H., Gautheron, C., Bernet, M., van der Beek, P., Paquette, J.L., Wang, A., Zhang, K.-X., Chevalier, M.-L., Li, H.-B., 2015. Timing and rate of 
exhumation along the Litang fault system, implication for fault reorganization in Southeast Tibet. Tectonics 34, 2014 TC003671.

Zhong, D. L., Ding L., Liu F. T., et al., 2000. Multi-oriented and layered structures of lithosphere in erogenic belt and their effects on Cenozoic magmatism-A case study of western Yunnan and Sichuan, China. Sci China Ser D-Earth Sci, 43(Suppll): 122-133.

Zi, J. W., Cawood, P. A., Fan, W. M., Tohver, E., Wang, Y. J., Mccuaig, T. C., 2013. Late Permian-Triassic magmatic evolution in the Jinshajiang orogenic belt, SW China and implications for orogenic processes following closure of the Paleo-Tethys. American Journal of Science 313, 81-112. 
Figure 1. Geological and tectonic settings of the Three Rivers region. a) Topography, active faults, and major suture zones in the Tibetan Plateau. b) Simplified geological map of Three Rivers region, superimposed on shaded relief. Sample locations in Deqin (DQ) and Weixi (WX) transects in this study are indicated by filled circles. Also shown are sample transects in previous publications, except those by Wilson and Fowler (2011) and Yang et al. (2016), whose samples are scattered, rather than in vertical transects. 1. Zhang et al. (2015); 2. Tian et al. (2014); 3. Ouimet et al. (2010); 4. Zhang et al. (2016); 5. Li and Zhang (2013); 6. Clark et al. (2005); 7. Tian et al. (2015); 8. Shen et al. (2016).

Figure 2. Geomorphology of the Three Rivers region. a) Shaded relief map. Shaded polygons mark high-elevation and low-relief surfaces. The river network is also shown. Thick colored lines are major suture zones. Active faults are shown as thin black lines. b) Swath

Figure 3. Sample locations near Deqin ( $a$ and b) and Weixi (c and d), superimposed on the geological map and shaded relief, respectively. Circles with red filling denote samples collected in 2011, and pale blue for 2009 reconnaissance samples. Major faults near sampling sites include F1: Lancang Jiang fault zone; F2: Zigashi-Deqin fault; F3: Deqin-Zhongdian fault; F4Weixi-Qiaohou fault; F5: Yangla-Tengtiao Jiang fault zone. Fault names are adopted from Chen et al. (1987).

Figure 4. Corrected AHe or ZHe ages versus effective uranium content [eU]. Panels a) and c) are for the Deqin transect, b) and d) for the Weixi transect. 
Figure 5. Plots of apatite (U-Th)/He (AHe), apatite fission track (AFT), and zircon (U-

752

753

754

755

756

757

758

759

760

761

762

763

764

765

766

767

768

769

770

771

772

773

774

775

776

777 $\mathrm{Th}) / \mathrm{He}(\mathrm{ZHe})$ ages against elevation for a) the Deqin transect of samples collected in 2011 and on the eastern bank of the Lancang river, b) all samples near the Deqin transect, including samples collected in 2011 on the western bank of Lancang, samples collected in 2009 of this study, as well as samples in previous studies of Yang et al. (2015) and Wilson and Fowler (2011), c) the Weixi transect with only samples collected in 2011, and d) the Weixi transect with both 2009 and 2011 samples. Also shown are best least-squares fitting lines of the exhumation rates for samples considered in vertical profile, using the method by Glotzbach et al. (2011). The method yields minimum, maximum, and mean slopes in ageelevation relationship for each dataset, taking into account of thermochronometric ages and their uncertainties of dated grains. Deqin transect (panel a) suggests a roughly uniform exhumation rates for all three closure temperatures. Samples with elevation below $3500 \mathrm{~m}$ have younger AFT and ZHe ages than those above. Samples labeled as "MK" refer to those by Yang et al (2016), "YA" referring to those by Wilson and Fowler (2011). Samples collected in 2009 (unfilled symbols) are not used in calculating the exhumation rate, because they are located far to be not considered part of the vertical transect. One outlier in the Weixi transect (11-01; panel b) is also shown with unfilled symbol.

Figure 6. Stacked pseudo-elevation vs. cooling ages plot for a) Deqin and b) Weixi transects. Pseudo-elevation of a sample refers to the height above the closure depth of the corresponding thermochronometer (AHe, AFT or $\mathrm{ZHe}$ ), relative to the mean elevation of the sample transect. Gray lines indicate exhumation rate variation over time.

Figure 7. Average erosion rate plotted against varying geothermal gradients for the a) AHe, b) AFT, and c) ZHe ages of DQ transect, and the d) AHe, e) AFT, and f) ZHe ages of the Weixi transect, using the method of Willett and Brandon (2013).

Figure 8. Simplified geologic map showing the distributions of faults, suture zones, Tertiary basins, and Eocene magmatic rocks. The faults in the Qiangtang terrane are highlighted in red. Sample transects in previous studies include only selected ones, which are 
in the vicinity, and on the hanging wall of reverse faults. Abbreviations for some major faults: DQF: Zigashi-Deqin fault; DQHF: Dingqu He fault; GZF: Ganzi fault; LCJF: Lancang Jiang fault; LMSF: Longmen Shan fault; LTF: Litang fault; NJF: Nu Jiang fault; RRF: Red River fault; XJHF: Xiaojin He fault; XJF: Xiao Jiang fault; XSHF: Xianshuihe fault; YLF: Yangla fault; YNXF: Yunongxi fault.

Figure 9. Schematic diagrams illustrating shifting locus of faulting activities, as indicated by different phases of fast exhumation in low-temperature cooling ages. Scenarios of tectonic activity of individual faults are inferred based on Chen et al. (1987), He et al. (1996) and Pan et al. (2004) and this study. Faults shown in red refer to those with evidence of being active during the corresponding periods. Note that quantitative data of faulting activity of most faults in the region is incomplete. Tectonic inversion from Cretaceous extension to Cenozoic contraction is inferred based on the activity of faults bounding Cretaceous basins in the Qiangtang terrane to the south (e.g. He et al., 1996). DQF: ZigashiDeqin fault; JSJFZ: Jinsha Jiang fault zone; LCJF: Lancang Jiang fault; NJF: Nu Jiang fault; WXF: Weixi-Qiaohou fault; YLF: Yangla fault; ZDF: Zhongdian-Deqin fault.

Table 1

Supplements S1-S3 and A1-A5. 
Fig1a

Click here to download Figure: Fig1a.pdf

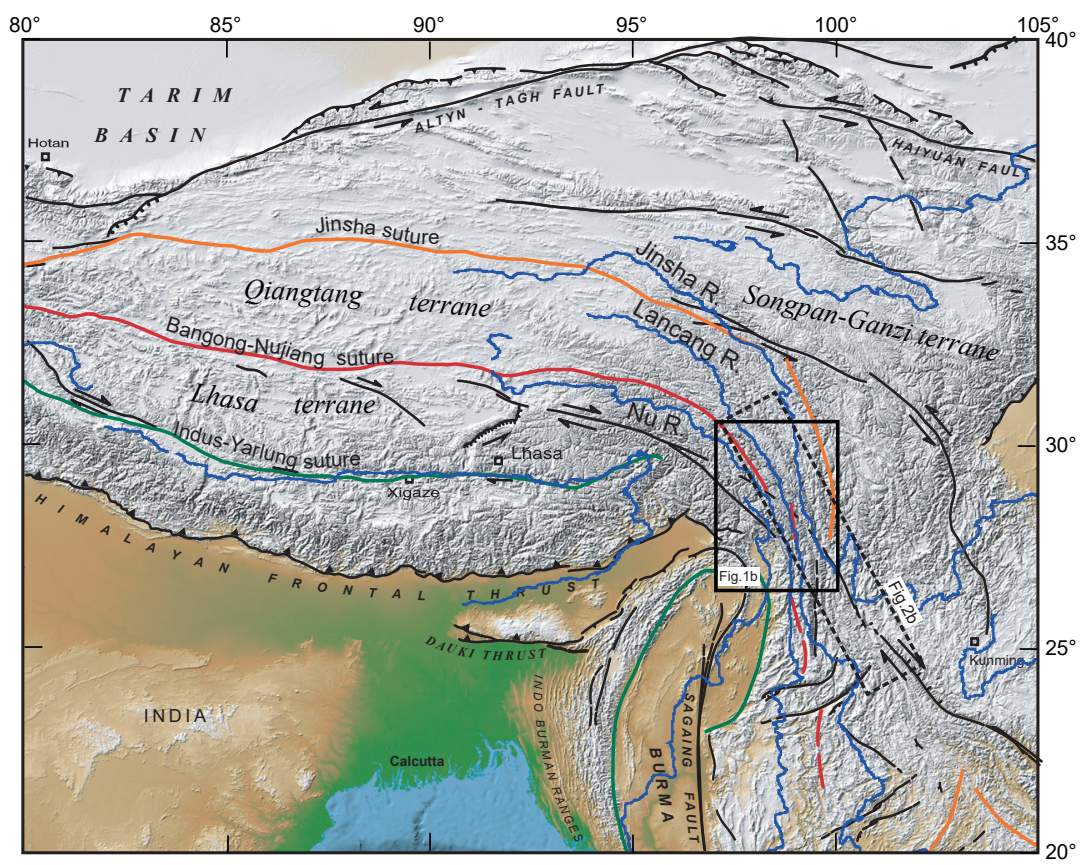

Fig. 1a 


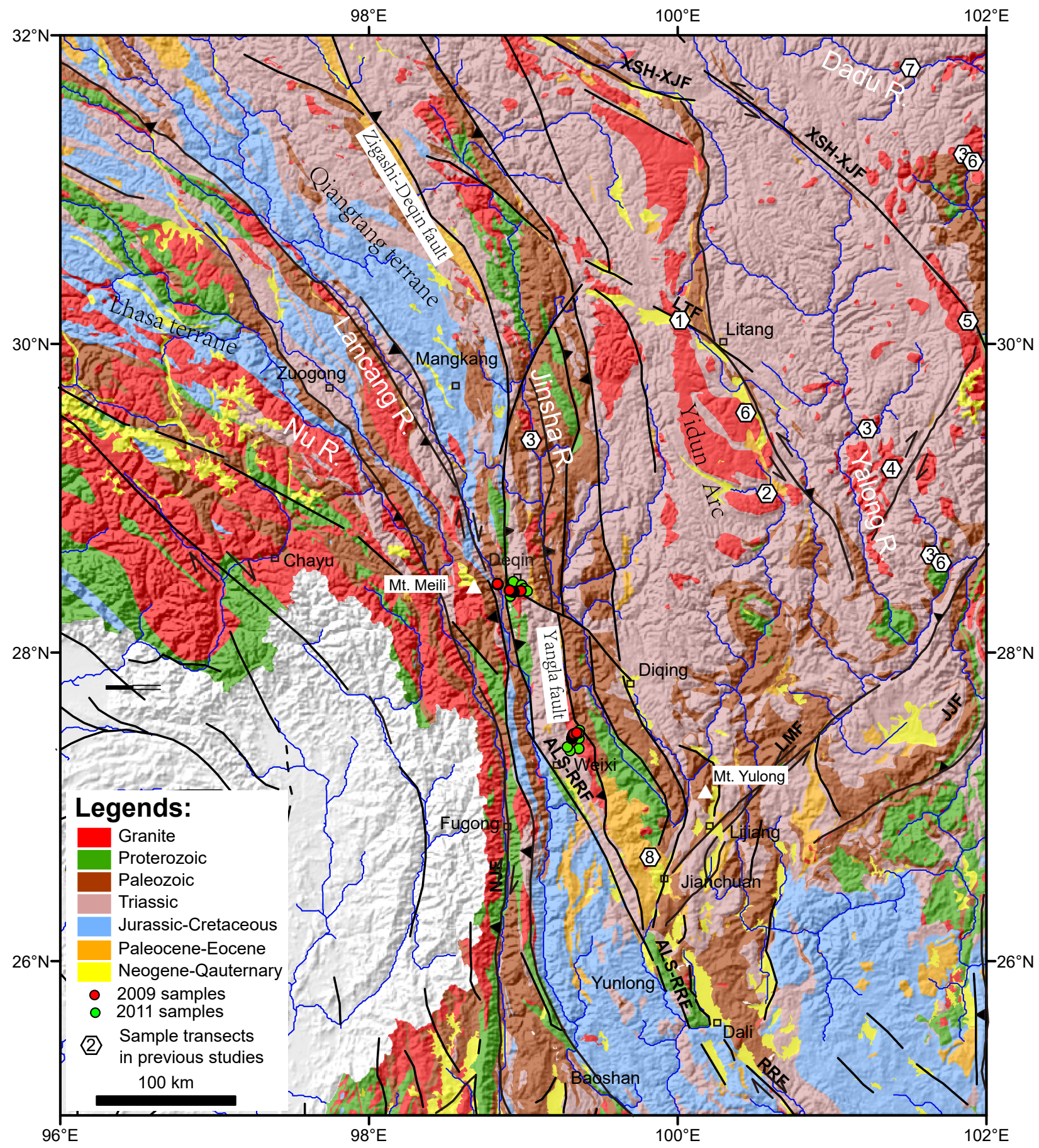




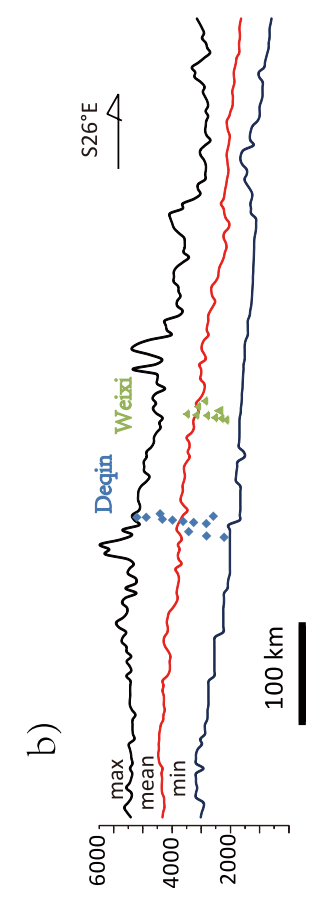

(u) иоำก리
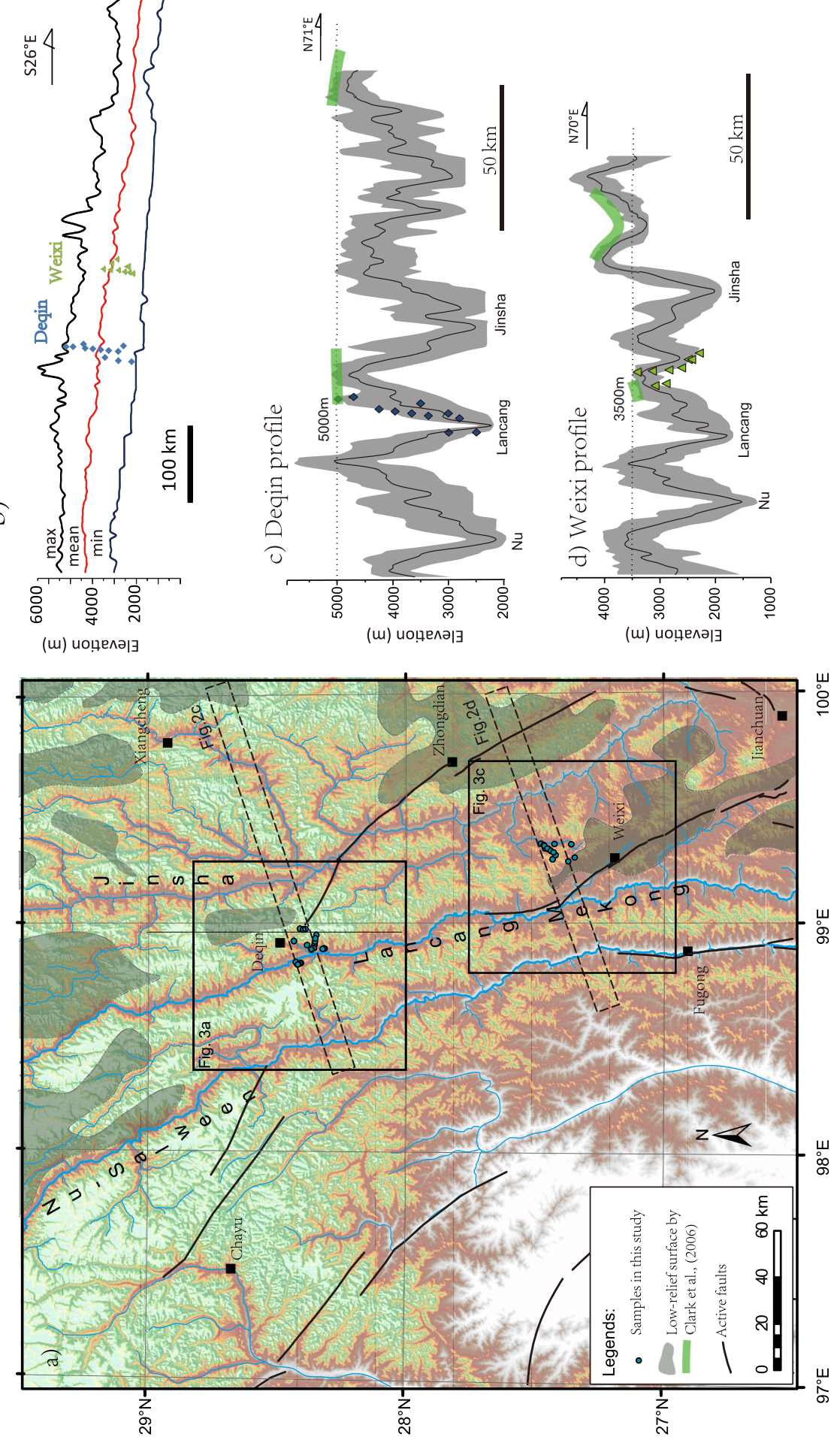

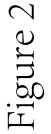


Fig3ab DQ c2

Click here to download Figure: Fig3ab DQ c2.pdf
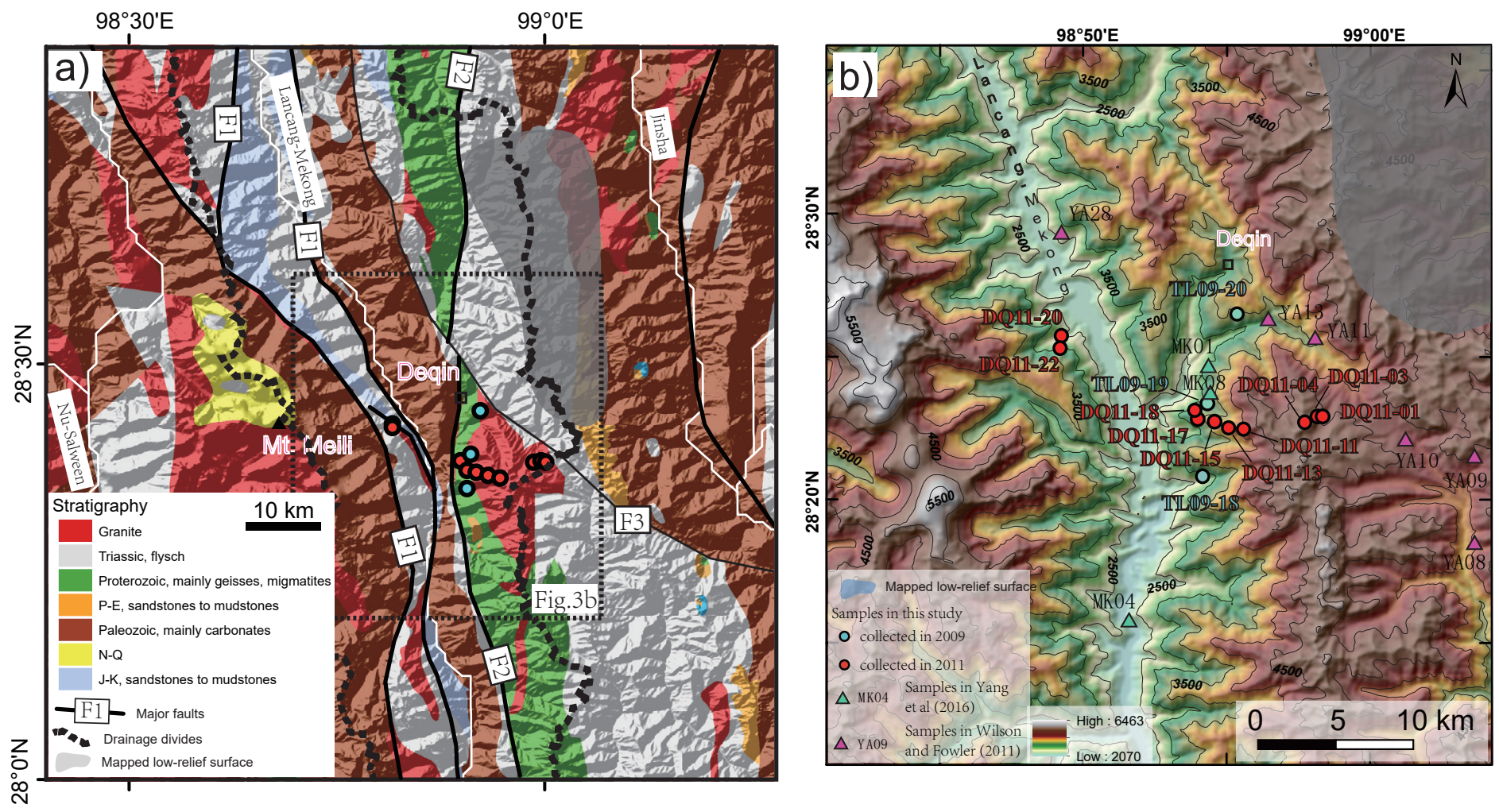

Figure $3 \mathrm{ab}$ 
Fig3cd Weixi c2

Click here to download Figure: Fig3cd Weixi c2.pdf

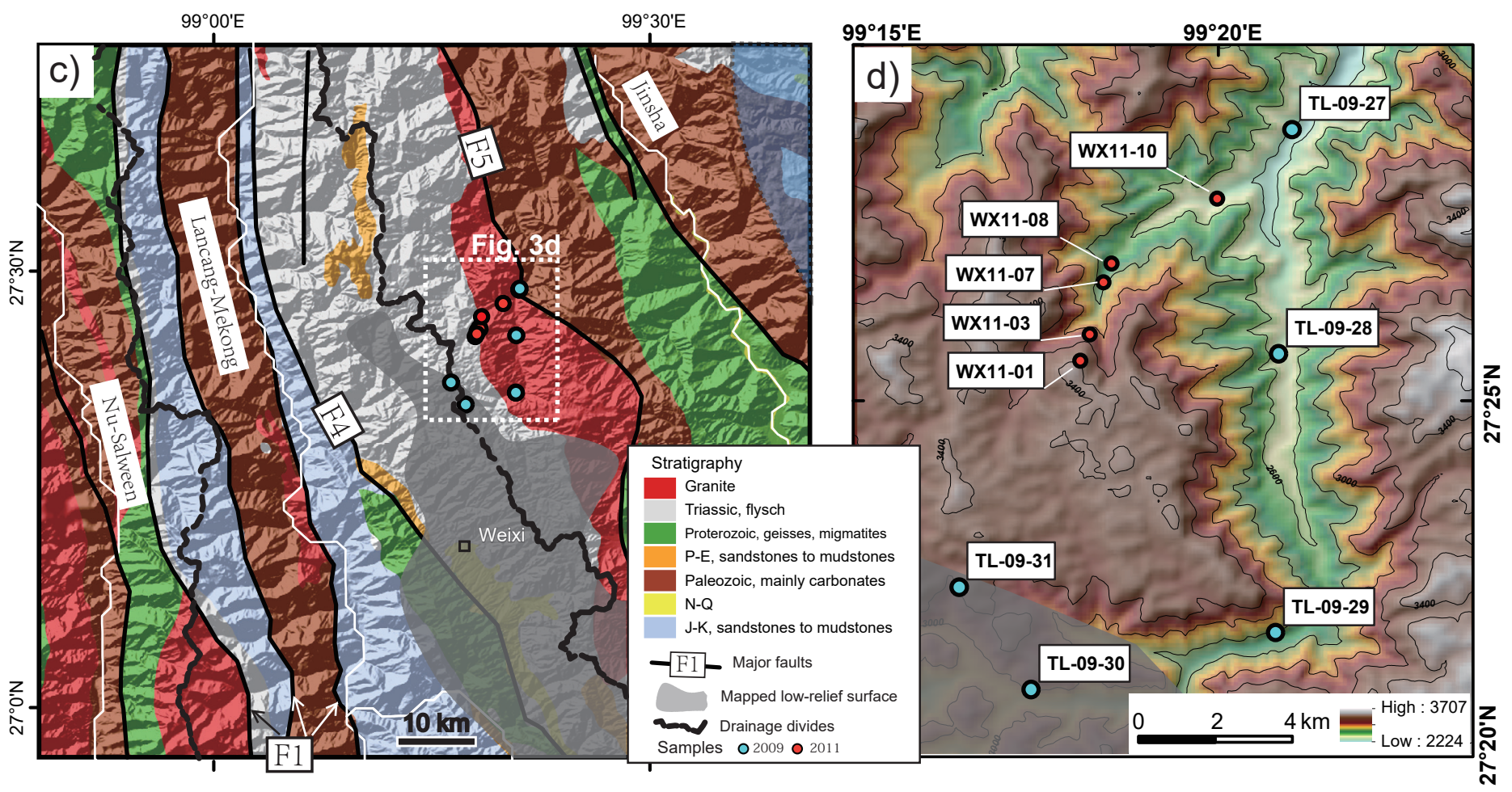

Figure $3 c d$ 

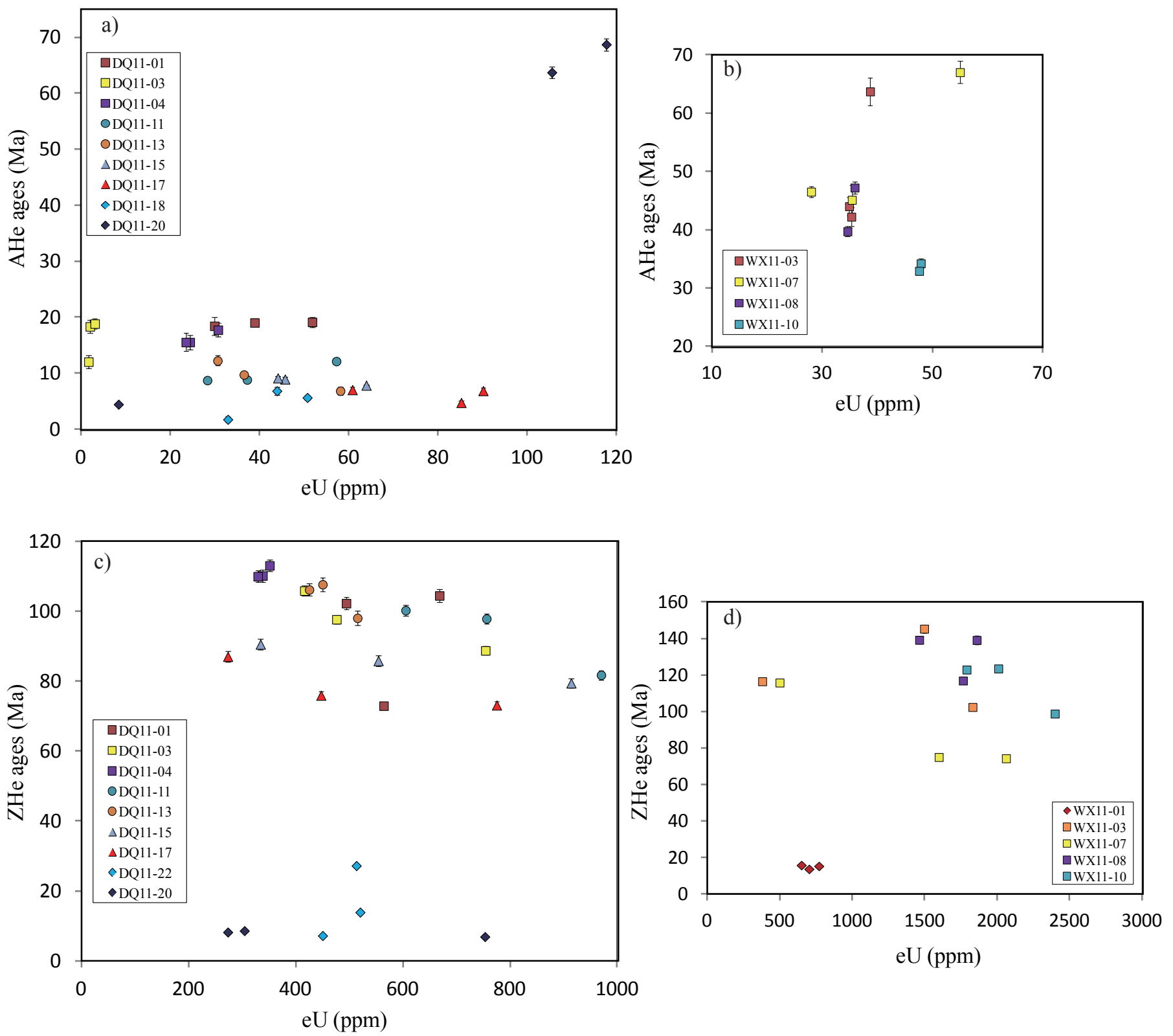

Figure 4 
a) Deqin transect sampled in 2011

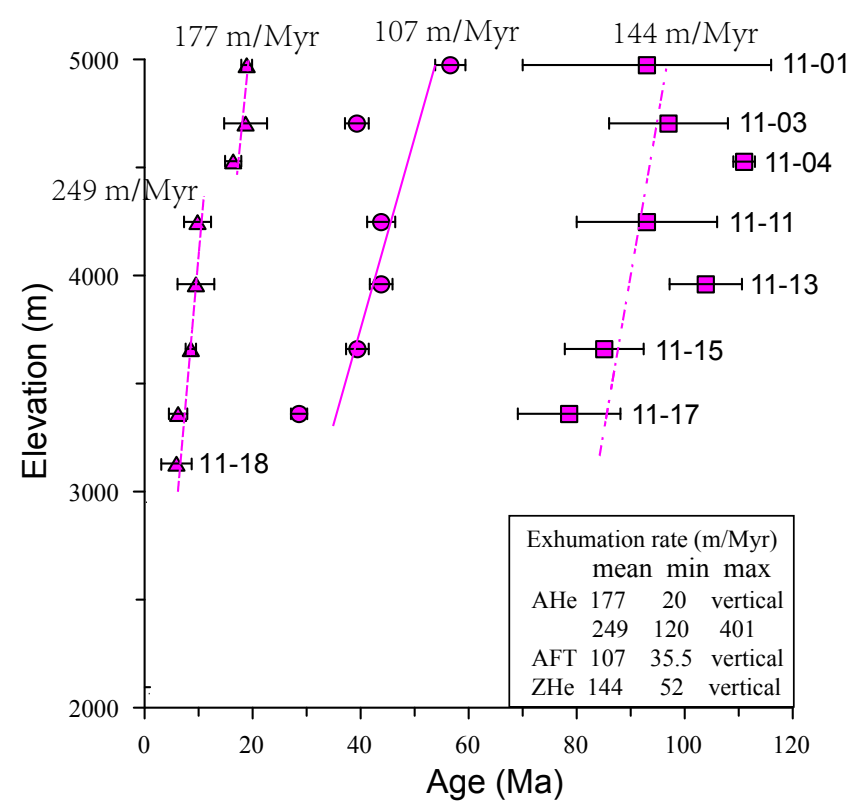

b) All samples near Deqin transect

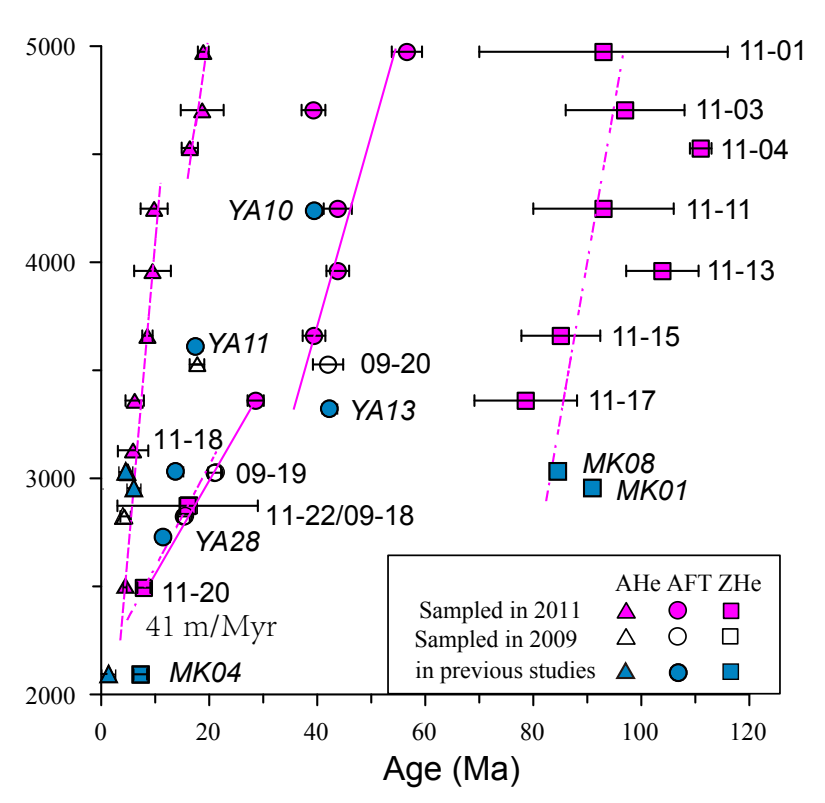

Figure 5ab 
c) Weixi transect sampled in 2011

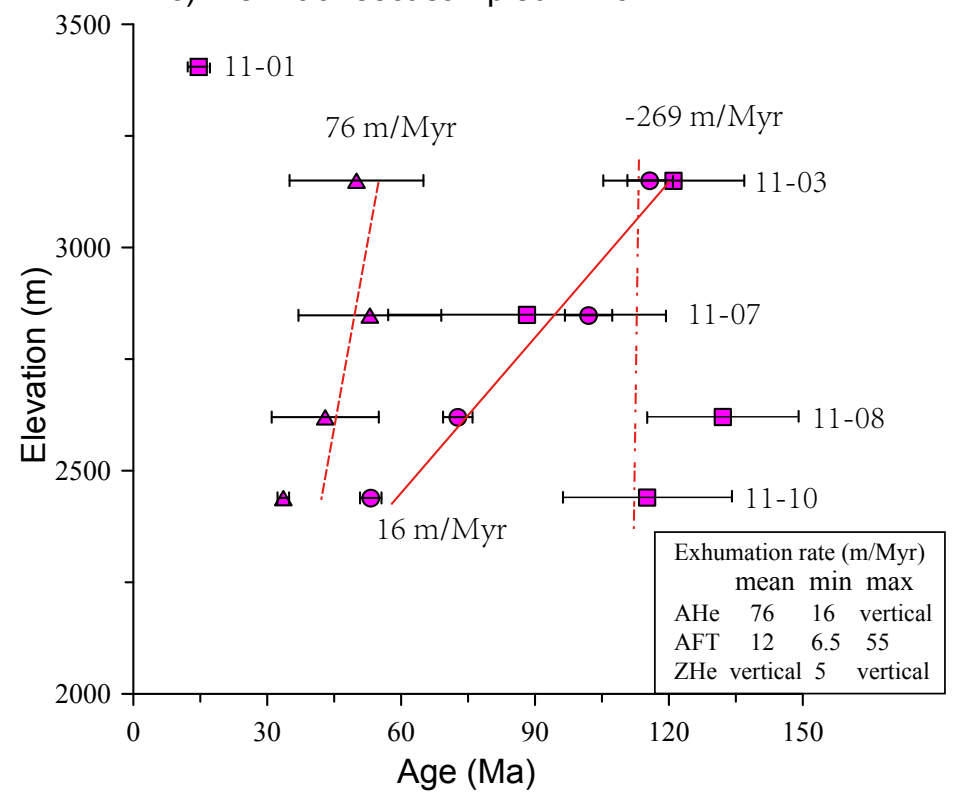

d) Weixi transect sampled in 2009 and 2011

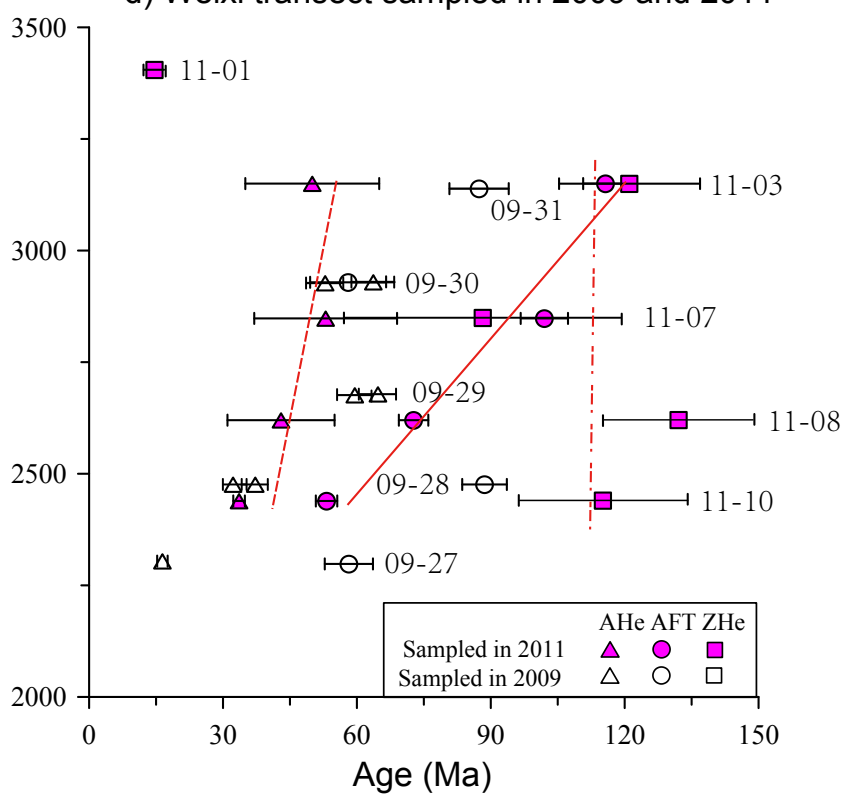

Figure 5cd 
Figure 6

Click here to download Figure: Fig6 2018-3.pdf
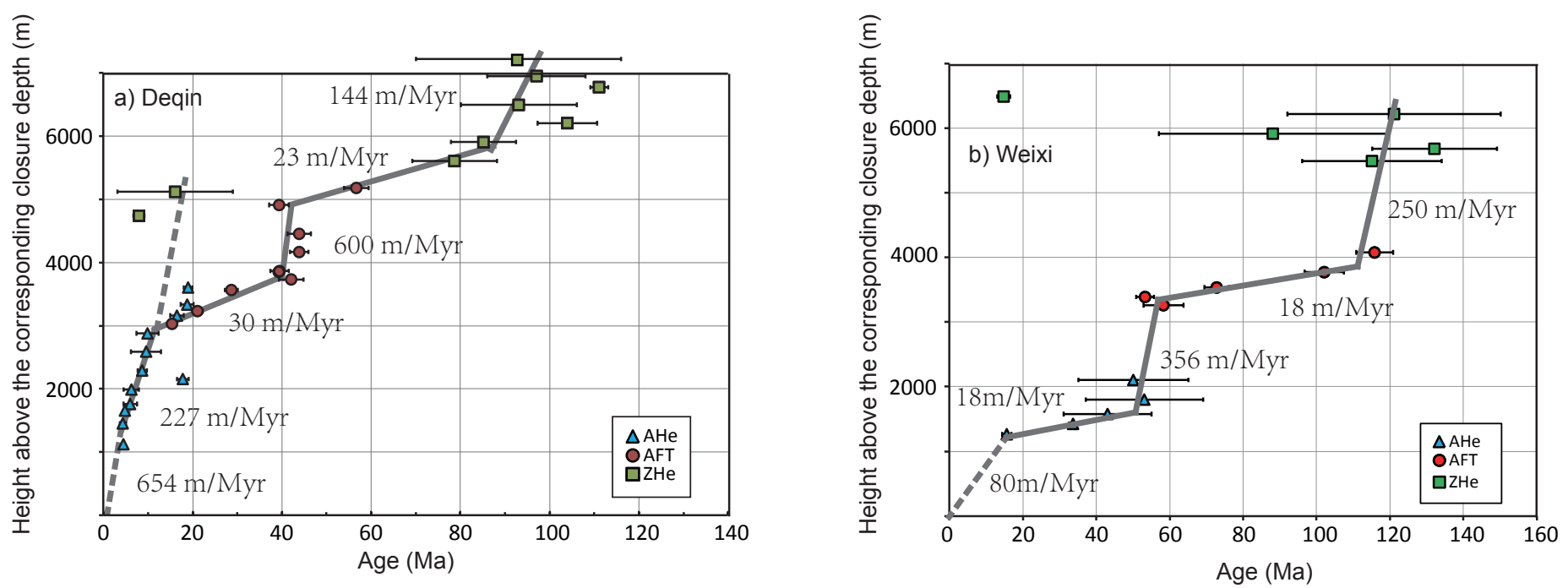

Figure 6 

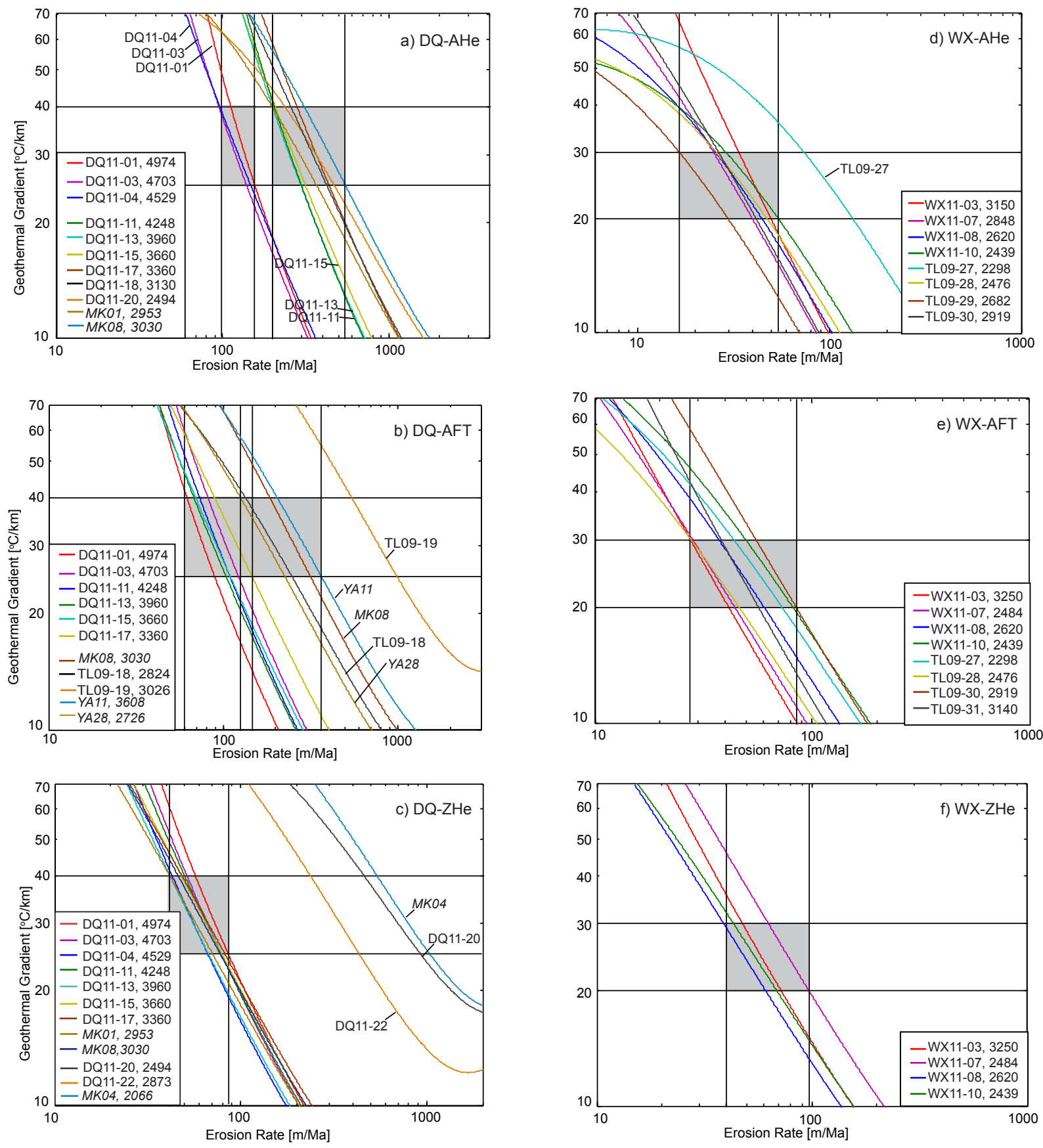

Figure 7 


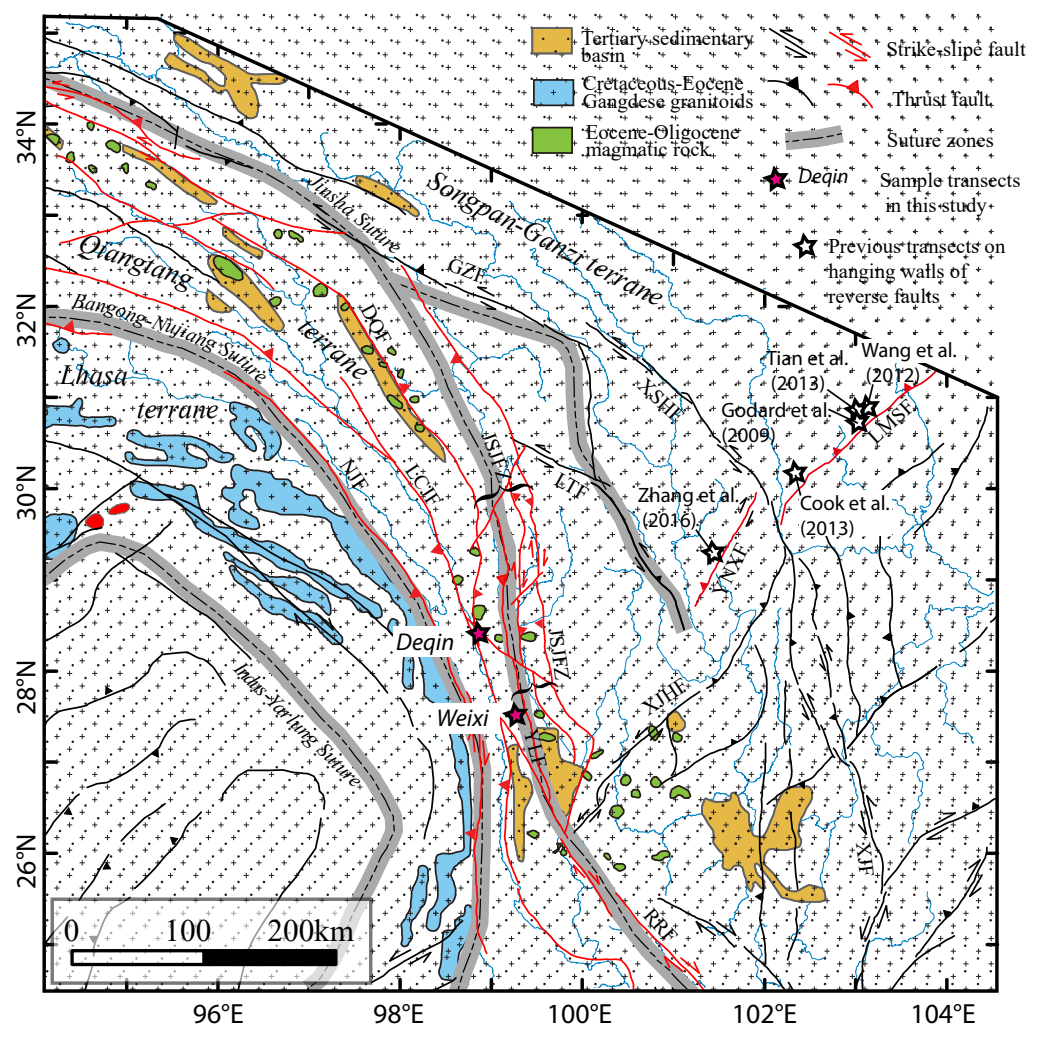

Figure 8 
a) $\sim 120 \mathrm{Ma}$

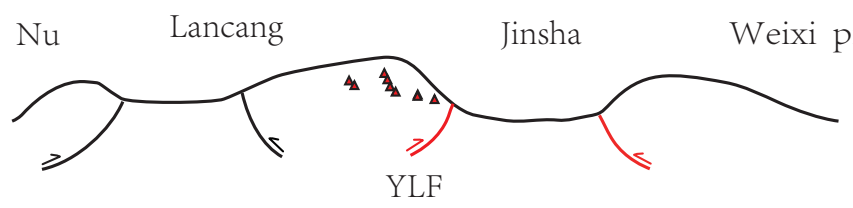

b) $100-80 \mathrm{Ma}$

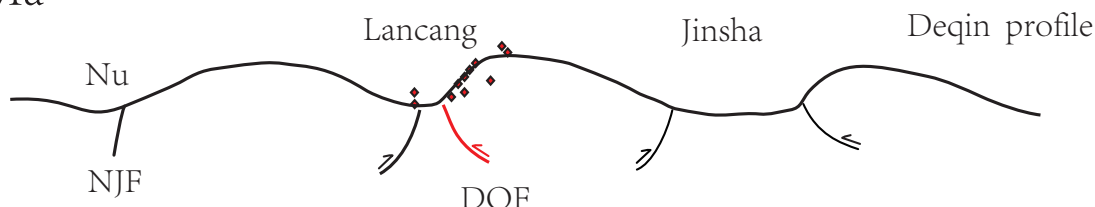

c) 60-50 Ma

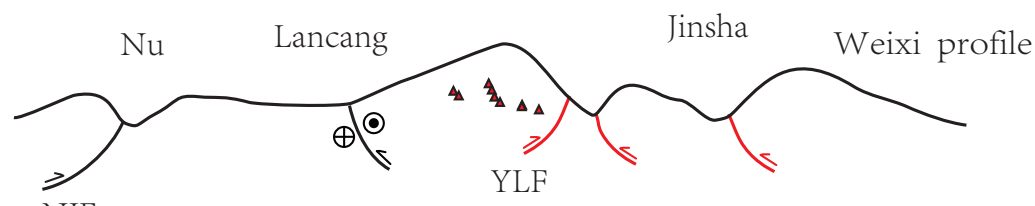

$\mathrm{NJF}$

d) $\sim 40 \mathrm{Ma}$

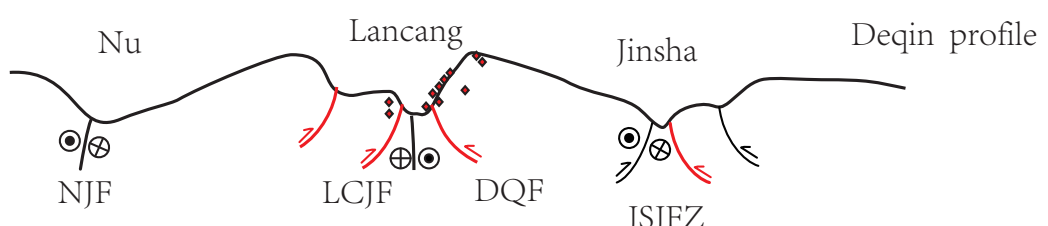

e) Since $20 \mathrm{Ma}$

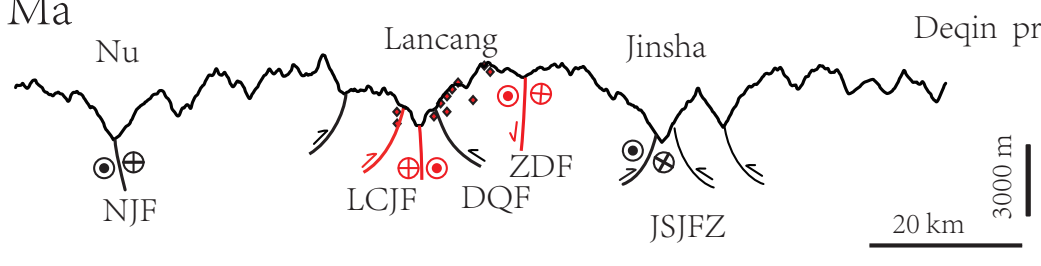

Figure 9 
Table 1. Geological information of 2009 and 2011 samples and a summary of mean AHe, ZHe and AFT ages.

\begin{tabular}{|c|c|c|c|c|c|c|c|}
\hline Sample ID* & $\begin{array}{c}\text { Latitude } \\
\left({ }^{\circ} \mathbf{E}\right)\end{array}$ & $\begin{array}{c}\text { Longitude } \\
\left({ }^{\circ} \mathbf{N}\right)\end{array}$ & $\begin{array}{c}\text { Elevat } \\
\text { on } \\
\text { (m) }\end{array}$ & Lithology & $\begin{array}{c}\text { Mean AHe** } \\
\quad(\mathrm{Ma}+1 \sigma)\end{array}$ & $\begin{array}{c}\text { AFT } \\
(\mathbf{M a}+\mathbf{1 \sigma})\end{array}$ & $\begin{array}{r}\text { Mean ZHe } \\
(\mathrm{Ma}+2 \sigma)\end{array}$ \\
\hline \multicolumn{8}{|c|}{ Deqin (DQ) } \\
\hline DQ11-01 & 28.3796 & 98.9616 & 4974 & Granodiorite & $18.9 \pm 1.0$ & $56.6 \pm 2.8$ & $93 \pm 23$ \\
\hline DQ11-03 & 28.37278 & 98.9687 & 4704 & Granodiorite & $16.4 \pm 3.8$ & $39.3 \pm 2.2$ & $97 \pm 11$ \\
\hline DQ11-04 & 28.3829 & 98.9720 & 4529 & Granodiorite & $16.4 \pm 1.5$ & N.D. & $111 \pm 2.0$ \\
\hline DQ11-11 & 28.3753 & 98.9263 & 4248 & Granodiorite & $9.8 \pm 2.5$ & $43.8 \pm 2.6$ & $93 \pm 13$ \\
\hline DQ11-13 & 28.3762 & 98.9176 & 3960 & Granodiorite & $9.5 \pm 3.4$ & $43.8 \pm 2.1$ & $103.9 \pm 6.7$ \\
\hline DQ11-15 & 28.3797 & 98.9091 & 3660 & Granodiorite & $8.6 \pm 1.0$ & $39.4 \pm 2.1$ & $85.1 \pm 7.3$ \\
\hline TL09-20 & 28.4423 & 98.9224 & 3527 & Granodiorite & $\begin{array}{l}17.4 \pm 1.1 \\
/ 18.0 \pm 1.1\end{array}$ & $42 \pm 2.8$ & N.D. \\
\hline DQ11-17 & 28.3814 & 98.8995 & 3360 & Granodiorite & $6.2 \pm 1.7$ & $28.6 \pm 1.5$ & $78.6 \pm 9.5$ \\
\hline DQ11-18 & 28.3861 & 98.8203 & 3130 & Granodiorite & $4.7 \pm 2.7$ & N.D. & N.D. \\
\hline TL09-19 & 28.3903 & 98.9051 & 3026 & Granodiorite & $\begin{array}{l}4.7 \pm 0.3 \\
/ 4.8 \pm 0.3\end{array}$ & $21 \pm 1.2$ & N.D. \\
\hline TL09-18 & 28.3482 & 98.9025 & 2824 & Tonalite & $\begin{array}{l}3.8 \pm 0.2 \\
/ 4.7 \pm 0.3\end{array}$ & $15.3 \pm 1.1$ & N.D. \\
\hline DQ11-22 & 28.4225 & 98.8196 & 2873 & Tonalite & N.D. & N.D. & $16 \pm 13$ \\
\hline DQ11-20 & 28.4296 & 98.8203 & 2494 & Tonalite & $4.4 \pm 0.3$ & N.D. & $7.9 \pm 1.2$ \\
\hline \multicolumn{8}{|c|}{ Weixi (WX) } \\
\hline WX11-01 & 27.4254 & 99.3006 & 3420 & Granodiorite & N.D. & N.D. & $14.7 \pm 1.7$ \\
\hline WX11-03 & 27.4307 & 99.3031 & 3150 & Rhyolite & $50 \pm 15$ & $115.7 \pm 5.0$ & $121 \pm 29$ \\
\hline TL09-31 & 27.3716 & 99.2723 & 3140 & Syenite & N.D. & $88.3 \pm 6.5$ & N.D. \\
\hline TL09-30 & 27.3476 & 99.2892 & 2919 & $\begin{array}{l}\text { Granite } \\
\text { Porphyry }\end{array}$ & $\begin{array}{l}63.37 \pm 3.80 \\
152.22 \pm 3.1\end{array}$ & $58.1 \pm 8.3$ & N.D. \\
\hline WX11-07 & 27.4351 & 99.3052 & 2848 & Diorite & $53 \pm 16$ & $102.0 \pm 5.3$ & $88 \pm 31$ \\
\hline TL09-29 & 27.3609 & 99.3466 & 2682 & Granodiorite & $\begin{array}{l}59.2 \pm 3.6 \\
/ 64.56 \pm 3.9\end{array}$ & N.D. & N.D. \\
\hline WX11-08 & 27.4478 & 99.3080 & 2620 & Granodiorite & $43 \pm 12$ & $72.7 \pm 3.3$ & $132 \pm 17$ \\
\hline TL09-28 & 27.4264 & 99.3473 & 2476 & $\begin{array}{l}\text { Granite } \\
\text { Porphyry }\end{array}$ & $\begin{array}{l}38.6 \pm 2.3 \\
136.3 \pm 2.2\end{array}$ & $88.6 \pm 5$ & N.D. \\
\hline WX11-10 & 27.4629 & 99.3327 & 2439 & Granite & $33.6 \pm 1.1$ & $53.2 \pm 2.4$ & $115 \pm 19$ \\
\hline TL09-27 & 27.4790 & 99.3504 & 2298 & Granodiorite & $\begin{array}{l}16.1 \pm 1.0 \\
/ 15.0 \pm 0.9\end{array}$ & $58.2 \pm 5.4$ & N.D. \\
\hline
\end{tabular}

* Granitic samples were all of Triassic in age. Some samples were collected in 2009, whose label starting with "TL09_“.

** For 2009 samples, AHe are multi-grain measurements, with two replicates. Two ages are listed separately. For 2011 samples, single grain measurements were conducted for both apatite and zircon, mostly with three replicates (with a couple of exceptions shown in supplementary tables A1 and A2). Listed are the weighted mean ages, which are calculated using Isoplot/Ex_ver3 (Ludwig, 2003).

N.D. Not determined. 

Supplementary material for online publication only
Click here to download Supplementary material for Click here to download Supplementary material for online publication only: Supplements S1-A5 re clean.docx

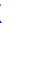

